\title{
Intestinal Permeation Enhancers for Oral Delivery of Macromolecules: A Comparison between Salcaprozate Sodium (SNAC) and Sodium Caprate $\left(\mathrm{C}_{10}\right)$
}

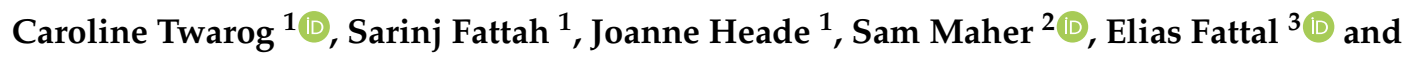 \\ David J. Brayden $1, * \mathbb{B}$ \\ 1 UCD School of Veterinary Medicine and UCD Conway Institute, University College Dublin, Belfield, \\ Dublin 4, Ireland; caroline.twarog@ucdconnect.ie (C.T.); sarinj.fattah@ucd.ie (S.F.); \\ joanne.heade@ucdconnect.ie (J.H.) \\ 2 School of Pharmacy, Royal College of Surgeons in Ireland, St. Stephen's Green, Dublin 2, Ireland; \\ sammaher@rcsi.ie \\ 3 School of Pharmacy, Institut Galien, CNRS, Univ. Paris-Sud, Univ. Paris-Saclay, 92290 Châtenay-Malabry, \\ France; elias.fattal@u-psud.fr \\ * Correspondence: david.brayden@ucd.ie; Tel.: +3531-716-6013
}

Received: 21 January 2019; Accepted: 11 February 2019; Published: 13 February 2019

\begin{abstract}
Salcaprozate sodium (SNAC) and sodium caprate $\left(\mathrm{C}_{10}\right)$ are two of the most advanced intestinal permeation enhancers (PEs) that have been tested in clinical trials for oral delivery of macromolecules. Their effects on intestinal epithelia were studied for over 30 years, yet there is still debate over their mechanisms of action. $\mathrm{C}_{10}$ acts via openings of epithelial tight junctions and/or membrane perturbation, while for decades SNAC was thought to increase passive transcellular permeation across small intestinal epithelia based on increased lipophilicity arising from non-covalent macromolecule complexation. More recently, an additional mechanism for SNAC associated with a $\mathrm{pH}$-elevating, monomer-inducing, and pepsin-inhibiting effect in the stomach for oral delivery of semaglutide was advocated. Comparing the two surfactants, we found equivocal evidence for discrete mechanisms at the level of epithelial interactions in the small intestine, especially at the high doses used in vivo. Evidence that one agent is more efficacious compared to the other is not convincing, with tablets containing these PEs inducing single-digit highly variable increases in oral bioavailability of payloads in human trials, although this may be adequate for potent macromolecules. Regarding safety, SNAC has generally regarded as safe (GRAS) status and is Food and Drug Administration (FDA)-approved as a medical food (Eligen ${ }^{\circledR}$-Vitamin $B_{12}$, Emisphere, Roseland, NJ, USA), whereas $\mathrm{C}_{10}$ has a long history of use in man, and has food additive status. Evidence for co-absorption of microorganisms in the presence of either SNAC or $\mathrm{C}_{10}$ has not emerged from clinical trials to date, and long-term effects from repeat dosing beyond six months have yet to be assessed. Since there are no obvious scientific reasons to prefer SNAC over $\mathrm{C}_{10}$ in orally delivering a poorly permeable macromolecule, then formulation, manufacturing, and commercial considerations are the key drivers in decision-making.
\end{abstract}

Keywords: oral macromolecule delivery; oral peptides; sodium caprate; salcaprozate sodium; epithelial permeability; epithelial transport

\section{Introduction}

Despite an increasing trend in drug discovery and development in favor of biologics (macromolecules), poor oral availability remains a major impediment to even more widespread 
application. One group of macromolecules, peptides and proteins, are especially advocated due to excellent specificity, selectivity, safety, and efficacy. Indeed, a combined 240 were marketed since the 1980s [1]. Of that list, $12 \%$ have $<60$ amino acids, designating approximately 30 peptides from that total [2]. Over $90 \%$ of peptides are injectable formulations, with just $4 \%$ delivered orally, and even lower percentages delivered via the skin and airway routes [2]. Recent progress was made toward the development of oral formulations for peptides where there are scientific, patient acceptability, and commercial arguments for non-injectable alternatives, especially for those that are used chronically and require frequent dosing (e.g., glucagon-like peptide 1 (GLP-1) analogs) [3]. The oral route offers greater patient compliance and can generate large market sales for molecules working indirectly on the same overall biological target, even if overall efficacy is lower than parenteral options. This is the case for oral dipeptidyl peptidase 4 (DPP-4) small-molecule inhibitors in competition with injectable GLP-1 peptide analogs [4]. Oral administration of peptides is limited by local conditions within the gastro-intestinal (GI) tract except for two relatively low-molecular-weight (LMW) examples designed for systemic delivery: a microemulsion of cyclosporin (Neoral ${ }^{\circledR}$, Novartis, Switzerland) and a conventional solid-dose formulation of desmopressin (Minirin ${ }^{\circledR}$, Ferring, USA) [5]. However, these examples are exceptions based on the atypical macrocycle structures of the two peptides, yielding oral bioavailabilities (BA) of $30-40 \%$ for lipophilic cyclosporine in Neoral ${ }^{\circledR}$ and just $0.17 \%$ for the highly potent hydrophilic desmopressin, Minirin ${ }^{\circledR}[6]$.

\section{Challenges for Oral Delivery of Macromolecules}

Oral administration of hydrophilic macromolecules with a molecular weight (MW) above $1000 \mathrm{Da}$ remains a challenge due to susceptibility to $\mathrm{pH}$ and gastric/small intestinal enzymes, as well as low intestinal epithelial membrane permeability. The low permeability results from minimal passive or carrier-mediated transcellular permeation across phospholipid bilayers, as well as restricted paracellular transport via tight junctions. If they were small molecules, peptides would likely be assigned to Class III of the biopharmaceutics classification system (BCS), typically exhibiting high aqueous solubility (but not always) and low intestinal permeability. It is noteworthy that, even in the example of cyclosporine where the fraction absorbed $\left(f_{a b s}\right)$ is high, sensitivity to intestinal cytochrome P450 metabolism and P-glycoprotein efflux reduce the BA [7]; its primary problem is intestinal wall metabolism, not permeability. Other variables also impact the feasibility of oral delivery of macromolecules. If the plasma half-life $\left(t_{\frac{1}{2}}\right)$ is too short, it will not be economically viable to administer a peptide candidate in multiple daily oral doses, where safety, efficacy, and variability issues would also arise. Similarly, a large therapeutic index (TI) is important in the context of selecting potent macromolecules as oral candidates, since efficacy and safety need to be addressed at the low and variable BA values that may be achieved even with successful oral formulations.

Investigators attempted to address pre-systemic degradation and poor permeation in the same formulation. A common approach is to combine peptidase inhibitors with absorption-modifying excipients (AMEs) or chemical permeation enhancers (PEs). These are usually formulated in enteric-coated dosage forms [6], although those formulated with salcaprozate sodium (SNAC), the leading candidate $\mathrm{PE}$ of the Eligen ${ }^{\circledR}$ technology (Emisphere, NJ, USA), do not seem to require coating [8]. In addition to avoiding degradation by gastric enzymes and low $\mathrm{pH}$, enteric-coated capsules and tablets avoid dilution and premature release of both PE and macromolecule in the stomach. Furthermore, coatings can assist in promoting co-release of both in high concentrations at the same region to maximize intestinal permeability [9], a formulation goal to maximize payload delivery. Incorporation of PEs in conventional oral dosage forms is considered a relatively basic technology approach to address macromolecule permeability [10]. However, the ease with which PEs can be incorporated into delivery systems without the need for sophisticated and costly formulation made them more commercially attractive compared to, for example, nanotechnology [11] and device-based systems [12]. The majority of formulations currently in clinical trials for oral peptides are, therefore, based on PEs, whereas most nanotechnology and device-based systems remain in preclinical research [6]. This scenario may change 
if PE-based formulations only prove efficacious and commercially viable for exceptions: highly potent, stable, long- $\mathrm{t}_{\frac{1}{2}}$ molecules of relatively low MW, and with a large TI.

\section{Intestinal Permeation Enhancers}

Numerous compounds including surfactants, bile salts, bacterial toxins, chelating agents, and medium-chain fatty acids (MCFA) proved to be effective PEs for poorly permeable molecules in in vitro and in vivo studies $[10,13]$. A comprehensive analysis of the majority of intestinal PEs from these classes that are used with peptides is available [10]. PEs that increase permeability across Caco-2 monolayers, isolated intestinal tissue mucosae, and in rodent models may also improve oral BA in humans, but this is not guaranteed since such studies are predominantly based on admixtures with payloads, not oral formulations. Furthermore, scale-up of the final formulation, PE dose, dilution, spreading, and release of both PE and payload during transit in the human GI tract, as well as the influence of enzymes, bile salts, and lipids in human intestinal fluids, must all be taken into account when attempting to make oral BA predictions for humans from preclinical studies. There are currently over 50 clinical trials in which PEs were shown to increase oral absorption of poorly permeable molecules, mostly achieved using surfactants [14]. The most widely tested PEs in these trials include Eligen ${ }^{\circledR}$ carriers, MCFAs, acyl carnitines, bile salts, and ethylenediaminetetraacetic acid (EDTA) [15]. The MCFA, sodium caprate $\left(\mathrm{C}_{10}\right)$, and the $\mathrm{C}_{8}$ derivative, salcaprozate sodium (SNAC), are of particular interest as they had over 20 years of development in proprietary delivery platforms and have been tested in human trials more than any other PEs. $\mathrm{C}_{10}$ was originally developed as the main component of an oral solid-dosage form (GIPET ${ }^{\mathrm{TM}}$, Gastro-Intestinal Permeation Enhancement Technology) by Elan Pharma (Dublin, Ireland), and then, following licensing, by Merrion Pharmaceuticals (Dublin, Ireland) for oral peptide delivery, and by Ionis Pharmaceuticals (Carlsbad, CA, USA) for oral delivery of antisense oligonucleotides. SNAC was developed by Emisphere (NJ, USA) as the lead agent of its Eligen ${ }^{\circledR}$ carrier technology. Novo Nordisk (Bagsværd, Denmark) licensed both GIPET ${ }^{\mathrm{TM}}$ and Eligen ${ }^{\circledR}$ to assess with their insulin and GLP-1 analogs, ultimately opting to focus on an SNAC tablet formulation with their highly potent, stable, long- $\mathrm{t}_{\frac{1}{2}}(160 \mathrm{~h})$ injectable GLP-1 analog, semaglutide, for advanced clinical development, while abandoning GIPET ${ }^{\mathrm{TM}}$, along with further attempts to create an oral insulin.

\section{Introducing $\mathrm{C}_{10}$}

$\mathrm{C}_{10}$ is the sodium salt of capric acid, an aliphatic saturated 10-carbon MCFA (Figure 1A). Fatty acids are ubiquitous nutrients liberated in high quantities during digestion of glycerides in the GI tract. They are also present in low $\mathrm{mM}$ concentrations in various nutrient sources, including milk. $\mathrm{C}_{10}$ is approved as a food additive in both the United States (US) and European Union (EU) and there are no daily limits on consumption; it was recently concluded that its presence in food should have no impact on human health [16]. $\mathrm{C}_{10}$ was a component of an approved rectal suppository of ampicillin (Doktacillin ${ }^{\circledR}$, Meda, Solna, Sweden) [17]. It was since assessed in clinical trials by Merrion Pharma as oral solid-dosage forms $\left(\mathrm{GIPET}^{\mathrm{TM}}\right)$ for the delivery of a wide range of poorly permeable actives, including small molecules (e.g., zoledronic acid, alendronate) and macromolecules (insulin, desmopressin, acyline, and antisense oligonucleotides) [18]. $\mathrm{C}_{10}$ is a soluble anionic surfactant, sensitive to changes in $\mathrm{pH}$ and ionic strength. At $\mathrm{pH}$ values $1-3$ units below its $\mathrm{pKa}(\sim 5)$ in gastric fluid, it exists in the non-ionized, insoluble, and inactive capric acid form. At acidic $\mathrm{pH}$ values, the surfactant can reduce surface tension, but does not exhibit detergent action. At $\mathrm{pH}$ values 1-3 units above its $\mathrm{pKa}$ (i.e., values that typically occur in the small intestine), $\mathrm{C}_{10}$ exists in an ionized soluble form with detergent capacity. Like many other efficient detergents, it does not form micelles efficiently owing to repulsion between the charged hydrophilic head groups. The resulting high concentration of free monomeric surfactant enables epithelial plasma membrane interaction and confers a transcellular element to its mode of action. The critical micellar concentration (CMC) value of $\mathrm{C}_{10}$, like other ionizable surfactants, varies depending on the medium composition. Micelles form at lower concentrations in higher-ionic-strength buffers because the counter-ions in media interact closely 
with anionic head groups. Thus, varying the ionic strength alters the free monomeric concentration of $\mathrm{C}_{10}$ in the small intestine.

\section{Introducing SNAC}

SNAC is a synthetic $N$-acetylated amino-acid derivative of salicylic acid (Figure 1B). It was discovered as part of a screen to identify carrier-based PEs that could "chaperone" poorly permeable payloads across the intestine [19]. The carrier library of over 1500 compounds was collectively termed Eligen ${ }^{\circledR}$, and it formed the portfolio of Emisphere Technologies. SNAC is the most extensively tested carrier and the only PE approved in an oral formulation designed to improve oral BA, albeit with a small molecule, cyanocobalamin/SNAC [20]. It is important to note that this oral form of vitamin $\mathrm{B}_{12}$ was approved under the regulatory pathway for medical foods, which does not have to meet the standards required for drug approvals, although the regulatory requirements for medical foods are still much higher than those of dietary supplements [21]. Emisphere obtained generally recognized as safe (GRAS) status for SNAC, which was a requirement for developing cyanocobalamin/SNAC for the medical food regulatory pathway. Having GRAS status for this PE may have somewhat mitigated some of the perceived risks associated with the oral semaglutide program at Novo Nordisk. In the 1990s, initial focus on SNAC was aimed at developing an oral formulation of the poorly permeable macromolecule, heparin [22]. In other preclinical studies, it also improved intestinal permeation of peptides (salmon calcitonin (sCT) and insulin) [23], along with poorly permeable small molecules (e.g., cromolyn) [24]. SNAC was tested in many formats: taste-masked liquids, tablets, and soft gelatin capsules. Similar to $\mathrm{C}_{10}$, SNAC can be blended with the active pharmaceutical ingredient (API) using conventional processes, which makes manufacturing uncoated oral tablet dosage forms economic and relatively easy to scale.

It remains unclear if the high concentrations of SNAC required to improve small intestinal epithelial permeation relate to membrane perturbation, membrane fluidization, payload solubility changes, or tight junction openings, or whether it is a chaperone system that improves transcellular permeation via hydrophobization of the payload through non-covalent linkages. Of these factors and, unlike $C_{10}$, there is less direct evidence for tight junction involvement in the mechanism of SNAC than the other factors; hence, its common designation is as a transcellular PE. Common features are that $\mathrm{C}_{10}$ and SNAC are weak acids that display amphiphilicity and surface activity. However, there is a structural difference between them arising from the greater distribution of hydrophilic functional groups in the salicylamide region of SNAC, as evident from its higher polar surface area $\left(89.5 \AA^{2}\right)$ compared to $\mathrm{C}_{10}\left(40.1 \AA^{2}\right)[25,26]$. It follows that the hydrophobic region of SNAC should be less efficient at inserting into phospholipid membranes than $C_{10}$ [27]. This may be one of the reasons why higher concentrations of SNAC than $C_{10}$ are needed to improve permeation.
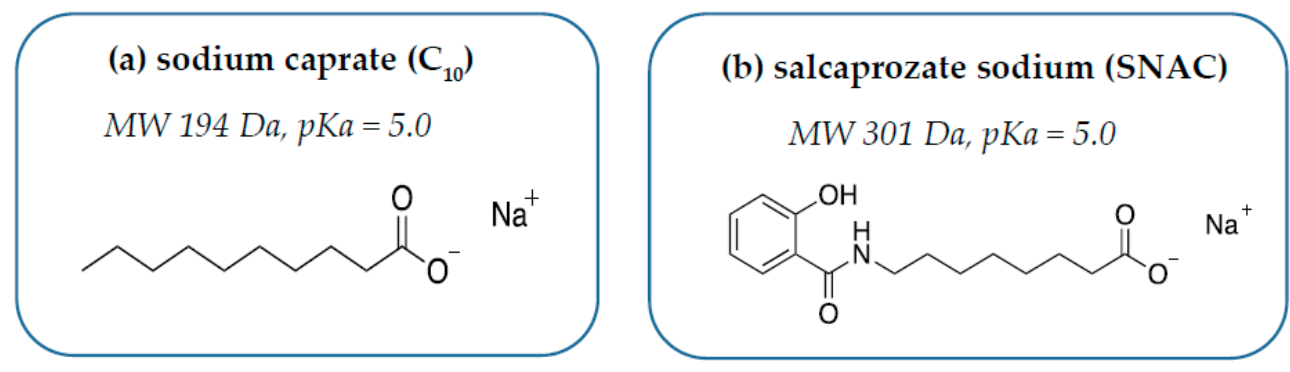

Figure 1. Structures of (a) sodium caprate $\left(\mathrm{C}_{10}\right)$ and $(\mathbf{b})$ salcaprozate sodium (SNAC).

\section{How Do SNAC and $C_{10}$ Alter GI Permeability?}

\subsection{Challenges in Determining Mechanism of Action}

PEs can improve permeability via a combination of mechanisms. Such mechanisms include opening tight junctions to increase paracellular permeability, decreasing mucus viscosity, inhibition of 
epithelial efflux pumps, complexation/hydrophobization of payload, increasing membrane fluidity, and (indirectly) via peptidase inhibition. The various mechanisms of action of $C_{10}$ and SNAC were studied using cell biology and physicochemical techniques including membrane fluorescence, Western blotting, electrophoretic mobility, molecular imaging, and physical analysis. More recent approaches to the study of the interactions between PEs and payloads use surface plasmon resonance [28], as well as accelerated capillary electrophoresis, and isothermal titrated calorimetry (ITC) [29]; however, these techniques are mostly restricted to simple physiological buffers rather than bio-relevant intestinal fluids. In particular, a concern is that intricate mechanisms determined in in vitro assays might not reflect the true mechanism, because the PE concentrations used in vitro are typically lower than the efficacious doses used in vivo. There is, therefore, uncertainty regarding the actual local concentrations of PE and payload at the small intestinal epithelial wall in a particular region due to variability in dissolution, spreading, and dilution in the human GI lumen during transit.

\section{2. $C_{10}$ Mode of Action}

The mode of action of $C_{10}$ was studied at great lengths in a range of delivery models. In summary, concentrations that lead to alteration to permeability coefficients or oral BA are associated with mild mucosal damage and other hallmarks of transcellular perturbation. At low concentrations, increases in permeability of hydrophilic small molecules across Caco-2 monolayers using relatively low concentrations of $\mathrm{C}_{10}(2.5 \mathrm{mM})$ can be uncoupled from loss of monolayer integrity, accompanied by reversible reductions in transepithelial electrical potential (TEER) [27,30], indicative of a paracellular mechanism. The higher concentrations required to alter permeability in isolated rat and human intestinal tissue mucosae are associated with transcellular perturbation [31,32]. Mode-of-action studies at higher concentrations $(8-13 \mathrm{mM})$ in Caco-2 monolayers also allude to a paracellular mechanism involving activation of membrane-bound phospholipase $C$ [33-35]. The resulting increase in inositol 1,4,5-triphosphate (IP3) leads to an increase in intracellular calcium $\left(\mathrm{Ca}^{2+}\right)$, which in turn activates calmodulin and myosin light-chain kinase (MLCK). This event triggers the contraction of the peri-junctional actomyosin ring (PAMR) [36], permitting increased tight junction (TJ) permeability.

Nonetheless, these studies involving pharmacological inhibitors are not definitive proof of a discrete paracellular effect. Impedance spectroscopy in HT29/B6 human intestinal monolayers also supports the dataset showing that $C_{10}$ acts via a paracellular mechanism; this was associated with removal or redistribution of the TJ proteins claudin 5 and tricellulin [37]. However, in the absence of data supporting the absence of transcellular perturbation (a dye uptake assay), the data from this study do not provide conclusive evidence for a paracellular mode of action either. It is impossible to ignore the evidence from a wide range of studies that $C_{10}$ also disrupts cell membranes at 8-13 mM. $\mathrm{C}_{10}$ also caused Caco-2 cell leakage of intracellular ATP from Caco-2 cells [33], a likely consequence of plasma membrane perturbation. One interpretation is that cells respond to the initial membrane perturbation challenge by $\mathrm{C}_{10}$ with compensating intracellular signaling processes involved in mucosal repair, beginning with disbandment of TJs, and concluded by epithelial resealing [38].

Some of the strongest evidence in favor of a mechanism driven primarily by perturbation, however, comes from high content image analysis in live Caco-2 cells. $\mathrm{C}_{10}(2.5 \mathrm{mM})$ increased intracellular $\mathrm{Ca}^{2+}$ in Caco-2 cells prior to the plasma membrane permeability changes detected at 8.5 $\mathrm{mM}$ [27]. $\mathrm{C}_{10}(8.5-13 \mathrm{mM})$ altered both plasma and mitochondrial membrane integrity, indicative of perturbation; importantly, these were the minimum concentrations needed to induce a permeability increase. The elucidation of the primary mode of action as membrane perturbation was clarified by the capacity of $\mathrm{C}_{10}$ to preferentially displace claudins 4 and 5 from lipid rafts in MDCK cells, consistent with surfactant properties [39]. Other evidence comes from a recent surfactant screen using isolated rat intestinal mucosae in Ussing chambers, where $\mathrm{C}_{10}$ caused a concentration-dependent increase in epithelial histology damage [40]. Given the close association between permeation enhancement and mucosal perturbation in tissue and animal models, it was, therefore, not surprising that the cyto-protectant prostaglandin analog, misoprostol, prevented both the $\mathrm{C}_{10}$-induced increase in flux 
of hydrophilic markers across Caco-2 monolayers and cell damage [41]. From these arguments, it is likely that the high concentrations of $C_{10}$ used in tablets also cause a degree of mild reversible mucosal perturbation in vivo, not unlike that seen with aspirin, alcohol, and spicy foods [42]. In a study of a human rectal formulation of ampicillin with $C_{10}$, there was evidence of mild and reversible mucosal perturbation [17], although the data were confounded by the hyper-osmolarity of the formulation. While it is not possible to conclude that mucosal perturbation of the relatively static rectal mucosal compartment extrapolates directly to the small intestine where transit is relatively fast, it is likely that $\mathrm{C}_{10}$ causes mild and reversible regional perturbation within a short period at the high concentrations exposed to the small intestinal epithelium prior to its almost complete absorption within minutes.

There is a lack of understanding of the physicochemical aspects of how $\mathrm{C}_{10}$ interacts with mixed micelles in the small intestine in the fasted and fed states. Above its CMC of $25 \mathrm{mM}$ in physiological buffer [27], $\mathrm{C}_{10}$ forms micelles and there is a distinct ratio of monomer to micellar-bound material, as highlighted in a recent study on alkyl maltosides [43]. In simulated intestinal buffers, it is uncertain whether the payload is incorporated into or adsorbs onto colloidal structures (e.g., mixed micelles, vesicles, lipid droplets), or whether it admixes with the $C_{10}$ monomer. There is resulting confusion over which format the payload permeates. Thus, while one envisages a paracellular permeation route for polar macromolecules due to hydrophilicity, a transcellular pathway may also be available if $\mathrm{C}_{10}$-entrapped vesicles and mixed micelles adsorb payload. Figure 2 is a composite of the possible multiple effects of $C_{10}$ on intestinal epithelia.

\section{Paracellular permeability Transcellular permeability}

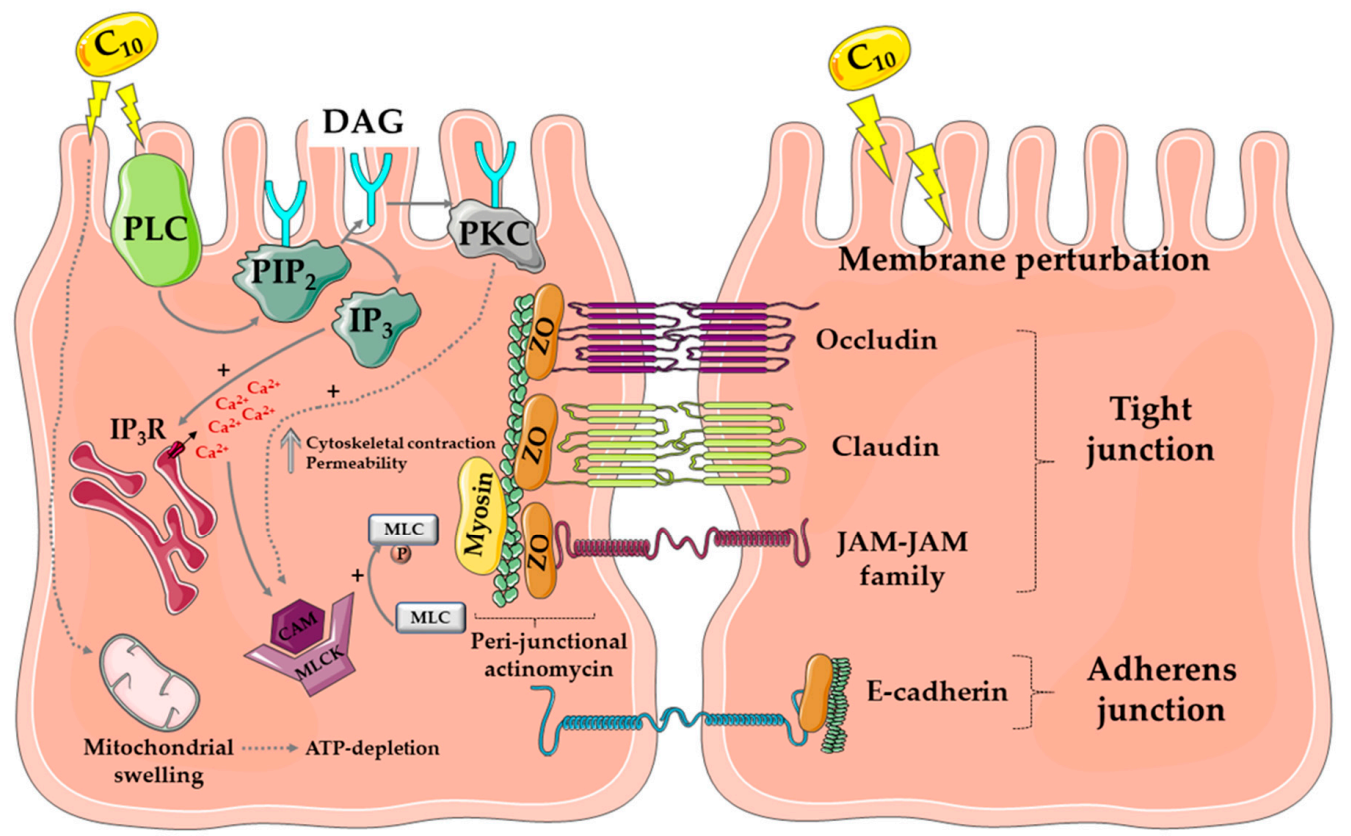

Figure 2. Mode of action of $C_{10}$. The diagram represents the proposed mechanism of action of $C_{10}$ via paracellular flux (left) and transcellular perturbation (right) to induce drug permeability across the intestinal mucosa. Abbreviations: PLC: phospholipase C; $\mathrm{PIP}_{2}$ : phosphatidylinositol 4,5-bisphosphate; DAG: di-acyl glycerol; PKC: protein kinase $C_{;} \mathrm{IP}_{3} \mathrm{R}$ : inositol triphosphate receptor; MLC: myosin light chain, CAM: calmodulin; ZO: zonula occludens; JAM: junctional adhesion molecule. Image created using a template from Servier Medical Art under a Creative Commons Attribution License.

\subsection{SNAC Mode of Action}

A different mode of action to that of $\mathrm{C}_{10}$ was proposed to explain how SNAC improves intestinal permeability. In the 1990s, Emisphere scientists proposed that SNAC improves passive transcellular permeation via hydrophobization. The hypothesis was that dipole-dipole non-covalent interaction 
between the carrier and structural moieties of the payload caused a conformational change in the latter, leading to exposure of hydrophobic regions that favor transcellular permeation. The interaction between SNAC and heparin [22,44] and with insulin [45] was, therefore, thought to be based on increased lipophilicity through hydrogen bonding and/or hydrophobic interactions, permitting dissolution of the complex in lipid bilayers. In support of this hypothesis, SNAC at a concentration of $17 \mathrm{mg} / \mathrm{mL}$ improved the permeation of insulin, but not that of radiolabeled mannitol across Caco-2 monolayers, suggesting that the effect was neither related to opening tight junctions nor to a decline in barrier integrity, and this interpretation was supported by confocal microscopy [45]. Higher concentrations of SNAC $(50 \mathrm{mg} / \mathrm{mL})$ that were more reflective of concentrations used in in vivo studies, however, caused complete loss of TEER and a 36-fold increase in $\left[{ }^{3} \mathrm{H}\right]-\mathrm{mannitol}$ permeability in Caco-2 monolayers [44], data that do not permit definitive conclusions to be made regarding mechanism since such high concentrations compromised the Caco-2 model. In isolated rat jejunal mucosae mounted in Ussing chambers, SNAC (33-66 mM) boosted the flux of a polar marker molecule, 6-carboxy-fluorescein (6-CF), but not that of $\left[{ }^{3} \mathrm{H}\right]$-mannitol across the epithelium and without reducing TEER values [46]. The authors argued that SNAC was indeed exploiting a transcellular pathway and not tight junctions to allow permeation of the hydrophilic polar ionized molecule (6-CF) and, somewhat controversially, they suggested that SNAC was reducing the charge on CF, thereby improving the capacity to partition in the epithelium. Similar to the Caco-2 study [44], when SNAC was added to jejunal mucosae at a concentration of $165 \mathrm{mM}$, TEER dropped and the permeability coefficient (Papp) of $\left[{ }^{3} \mathrm{H}\right]$-mannitol was increased [46], denoting a compromising event. Other Caco-2 studies also support a transcellular mechanism; Malkov et al. [47] detected intracellular signal increases ascribed to fluorescently labeled heparin and in the presence of SNAC, whereas immunohistochemistry data indicated that there were no changes of F-actin or the actinomycin ring during heparin flux. Ding et al. [48] used ITC and Fourier-transform infrared (FTIR) spectroscopy to study the interaction between cromolyn and SNAC, and concluded that the aromatic ring of SNAC inserted between those of cromolyn via its 2-hydroxybenzamide motif, leading to an increase in hydrophobicity of the complex and a reduction in cromolyn hydration. Lactate hydrogenase release $(\mathrm{LDH})$ measurements indicated that the increased cromolyn fluxes across Caco-2 monolayers in the presence of SNAC were not associated with cell damage.

Despite the elegance of the purported complex mechanism (Figure 3) of how SNAC might increase transcellular flux of multiple payloads, the hypothesis is problematic in several respects. If Eligen ${ }^{\circledR}$ carriers acted solely using dipole-dipole interactions via hydrophobization (and not an electrostatic interaction), it would be difficult to envisage a significant increase in passive permeation since the retention of ionized functional groups would impede passive movement across phospholipid bilayers.

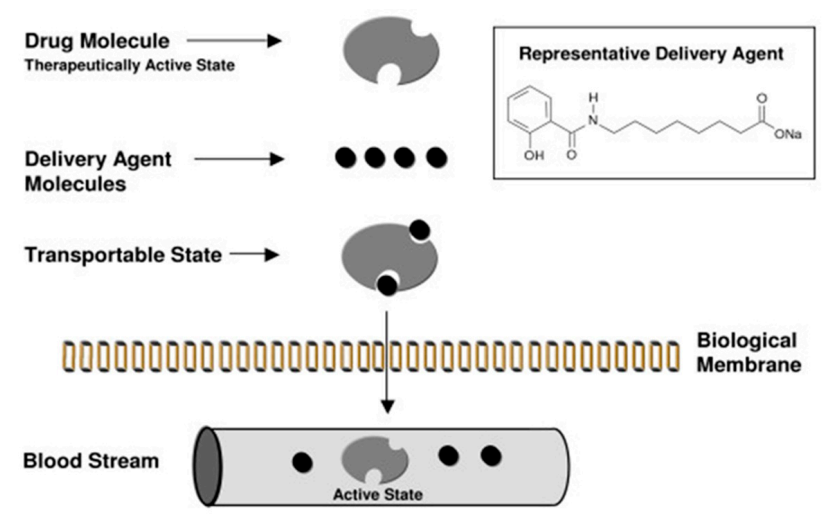

Figure 3. Schematic of Eligen ${ }^{\circledR}$ drug-delivery technology mechanism in intestinal epithelia, as advocated by Emisphere scientists in 2006. “Carrier molecule (delivery agent) associates with drug molecule to create a transportable complex (lipophilic). Because of the weak association, carrier and drug dissociate by simple dilution on entering the blood circulation." Reproduced from Reference [49] under the terms of the Creative Commons Attribution License. 
SNAC forms a conjugate base at the $\mathrm{pH}$ of the small intestinal lumen, so it can undergo complexation via hydrophobic ion pairing (HIP) with the conjugate acid of basic amino-acid side chains in macromolecules. However, HIP cannot fully account for Eligen ${ }^{\circledR}$-mediated hydrophobization of anionic payloads including heparin and cromolyn [24]. An alternative interpretation arises from another SNAC study with cromolyn; SNAC increased Caco-2 epithelial cell membrane fluidity as measured by fluorescence anisotropy, consistent with a surfactant-induced membrane perturbation effect, whereas in this study there was no increase in cromolyn's lipophilicity [50]. Still, the overall contribution of transcellular perturbation to the increased flux is not clear since the presence of hydrophilic functional groups in the salicylamide region of SNAC gives rise to inefficient micelle formation (CMC: $56 \mathrm{mM}$ in phosphate-buffered saline (PBS)) [50], and this will not favor membrane insertion. There are a number of other anomalies concerning the original chaperone transcellular mechanism proposed for SNAC (reviewed in Reference [49]). Firstly, since the structure of SNAC comprises MCFA and salicylic-acid moieties, non-specific detergent/surfactant effects on the epithelium should be expected. Secondly, the thermodynamic considerations with respect to the non-covalent linkage between SNAC and payload during epithelial flux are yet to be addressed. Furthermore, there were no calculations on the affinity of SNAC to payloads, except to assert that affinity was weak, now confirmed for exenatide [29]. Thirdly, a transcellular mechanism should account for epithelial endocytosis uptake pathways (e.g., via clathrin- or caveolae-mediated pathways or macropinocytosis), where a template to follow is in place for the other group of transcellular permeability-enhancing agents, the cell-penetrating peptides [51]. Finally, caution must be exercised in making definitive conclusions on mechanism using some of these assays; epithelial TEER values yield information on monolayer integrity, but reveal no direct information about tight junctions. Secondly, the absence of changes in tight-junction-associated antibody imaging for associated proteins is not definitive. Thirdly, fluorescently labeled payloads need to be assessed for their capacity to remain intact during flux. Finally, LDH release from monolayers following exposure to SNAC would not be regarded as a particularly sensitive assay, especially when increased membrane fluidization was observed. In sum, evidence from Caco-2 studies is not yet convincing enough to solely ascribe an exclusive transcellular mechanism for SNAC; moreover, there is little data to directly support the chaperone hypothesis. On the other hand, there are some differences between the mechanism of action of SNAC and those of PEs with mechanisms associated with tight-junction openings (e.g., EDTA).

Recently, Novo Nordisk offered a new mechanism of action for SNAC in its non-enteric coated tablet of the GLP-1 analog, semaglutide $\left(\mathrm{t}_{\frac{1}{2}}=160 \mathrm{~h}\right)$. Using a ligated dog model, they found that systemic delivery was achieved solely from stomach administration of the tablet [52]. The theory is that SNAC forms a complex around the semaglutide in the stomach and causes a transient increase in local $\mathrm{pH}$ around the molecule. It is claimed that semaglutide is protected against pepsin by SNAC and that solubility is increased, resulting in an increased concentration-dependent flux of semaglutide across the gastric mucosa, using a transcellular mechanism as the tablet comes in intimate contact with the epithelium. By shifting the emphasis toward elevation in stomach $\mathrm{pH}$ away from conformational changes and increased lipophilicity, the theory takes the focus away from membrane perturbation. Moreover, the authors argue that this mechanism is highly specific for semaglutide, in that similar studies with admixtures of SNAC and liraglutide led to no flux increase across in vitro gastric epithelial models [52]. Part of the role of SNAC seemed to be to convert semaglutide to a more permeable monomeric form and it seems to perform this better when formulated in a stomach-specific tablet. Is this payload-specific and region-specific theory entirely compatible with the previous data from small intestinal studies in which SNAC was paired with many payloads of differing structures? With new cell-imaging tools available, along with advanced biophysical methods to decipher the interaction between SNAC and payloads, it is likely that much of the discrepancy surrounding the mechanism of SNAC will be resolved. Figure 4 is a composite of the possible effects that SNAC has in the stomach when formulated with semaglutide. 


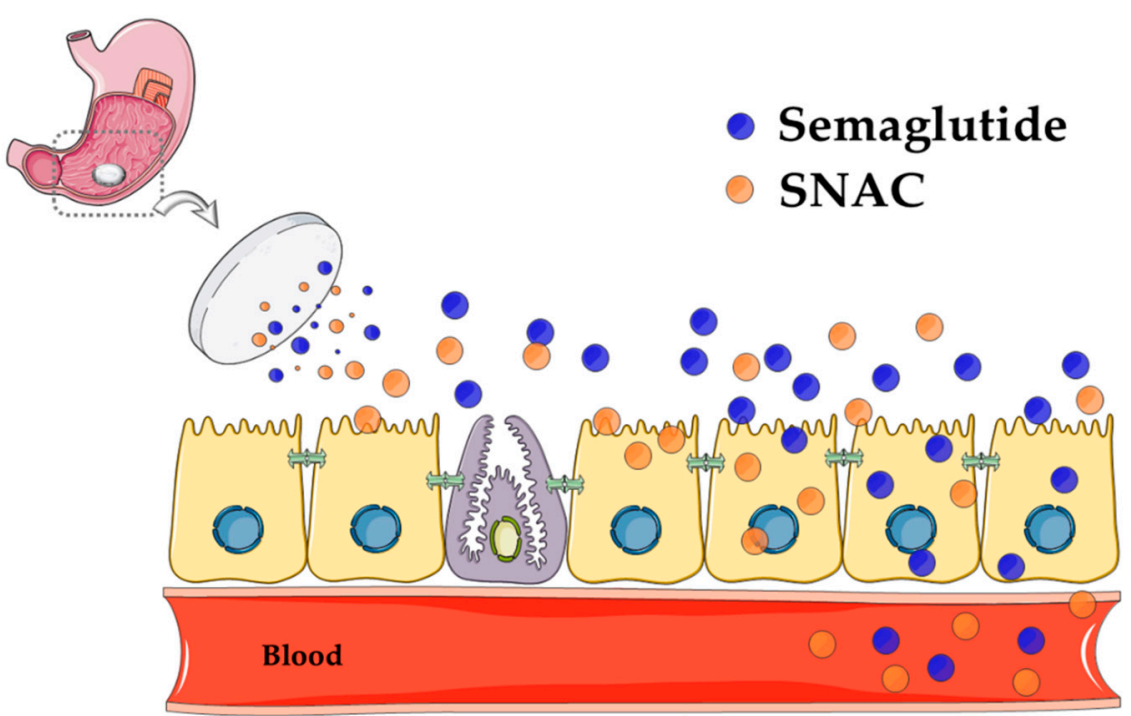

Figure 4. Theory of oral semaglutide absorption, as advocated by Novo Nordisk. Modified from Reference [52]. The diagram represents the proposed mechanism of action of SNAC in inducing transcellular flux of semaglutide across the gastric epithelium of the stomach. The optimum once-daily tablet consists of $14 \mathrm{mg}$ of semaglutide co-formulated with $300 \mathrm{mg}$ of SNAC. After digestion, the tablet erodes rapidly in the stomach, resulting in the release of a highly concentrated amount of SNAC that neutralizes the $\mathrm{pH}$ of gastric fluid in the immediate vicinity of the tablet to inactivate pepsin. SNAC is thought to induce semaglutide monomer production and increase gastric epithelial membrane fluidity, but without affecting tight junctions, thereby allowing transcellular passage of semaglutide into systemic circulation. The complex may dissociate at some point in the flux process (Figure 3) due to weak association, but direct evidence for this is scant. Black circles = semaglutide; white circles = SNAC. Image made using a template from Servier Medical Art under a Creative Commons Attribution License.

In sum, the in vitro studies on the mechanism of action of the two agents on cultured intestinal epithelia suggest some common surfactant-based features; however, in contrast to SNAC, there is direct evidence for tight-junction openings induced by $\mathrm{C}_{10}$. The culture models are sub-optimal, however, as they do not discriminate permeation enhancement from perturbation very well, nor do they predict in vivo consequences; the models have difficulty in tolerating both high concentrations of PEs and simulated intestinal fluids.

\section{7. $\mathrm{C}_{10}$ and SNAC: Pharmacokinetics and Efficacy in Clinical Trials}

\section{1. $C_{10}$}

GIPET $^{\mathrm{TM}}$ was advanced to clinical testing as enteric-coated tablets containing $\mathrm{C}_{10}$ with both peptide and small-molecule payloads [18,42]. Human studies using radiolabeled polyethylene glyol (PEG) revealed that the permeating enhancement effects of GIPET ${ }^{\mathrm{TM}}$ were transient and reversible in $<1 \mathrm{~h}$ [18]. GIPET ${ }^{\mathrm{TM}}$ was tested in a range of doses with several poorly absorbed molecules in a total of 16 Phase I studies comprising over 300 subjects [18]. Overall, while oral BA values of $>5 \%$ were cited for some molecules, the most notable feature was the massive intra-subject variability across all studies, constituting an issue for safety and efficacy.

Pharmacokinetics (PK) analysis of human trials for GIPET ${ }^{\mathrm{TM}}$ formulations with low-molecular-weight heparin $(\mathrm{LMWH})$ and desmopressin was described [18]. LMWH-GIPET $^{\mathrm{TM}}$ was formulated in tablets containing either 45,000 or $90,000 \mathrm{IU}$ of LMWH at two dose levels of $\mathrm{C}_{10}$. Oral BA was calculated relative to the standard sub-cutaneous (s.c.) dose of 3200 IU following administration to 14-16 subjects. Relative oral BA of 3.9-7.6\% was achieved [18]. With a high dose of LMWH combined with a high dose of $C_{10}$, increased levels of an anti-clotting biomarker were seen in all subjects; the responses were sustained and had a similar time course to the s.c. route. This particular formulation was not progressed 
clinically (Table 1). When desmopressin was formulated with GIPET ${ }^{\mathrm{TM}}$ and administered orally to 18 human subjects, a bioavailability of $2.4 \%$ relative to the s.c. route was detected [18], an improvement over the typical $0.2 \%$ value for Minirin ${ }^{\circledR}$ tablets. Again, this formulation was not progressed further. The GIPET ${ }^{\mathrm{TM}}$ technology was well tolerated even when repeatedly administered in these small Phase I studies [18]. Other clinical trial examples include the gonadotropin-releasing hormone $(\mathrm{GnRH})$ antagonist decapeptide, acyline. In a Phase I study of oral acyline, serum luteinizing hormone (LH), follicle-stimulating hormone (FSH), and testosterone were suppressed within $12 \mathrm{~h}$ at the 10-, 20-, and 40-mg single doses tested. However, sustained serum levels of acyline could not be detected, and there was no pharmacokinetic-pharmacodynamic (PK-PD) relationship [53]. The GIPET ${ }^{\mathrm{TM}}$ technology was also used to orally deliver the bisphosphonate, zoledronic acid. The rationale was that an oral tablet $\left(\right.$ Orazol $\left.^{\mathrm{TM}}\right)$ administered weekly by patients could compete with a monthly infusion of Zometa ${ }^{\circledR}$ in a hospital setting for cancer patients with bone metastasis. In a Phase I study, urinary excretion of unchanged zoledronic acid suggested equivalent delivery via both routes [54]. The licensing of GIPET ${ }^{\mathrm{TM}}$ to Novo Nordisk led to Phase I trials with respect to a proprietary insulin, NN1953, and a GLP-1 analog; however, the resulting data were never published and, ultimately, Merrion's remaining intellectual property (IP) assets were sold to Novo Nordisk, before being liquidated in 2016. Novo Nordisk in turn decided to move away from developing oral insulin to concentrate on its oral GLP-1 analog program. Nonetheless, an important Phase II trial from that time assessing a once-daily long-acting basal insulin (I338) with a $\mathrm{t} \frac{1}{2}$ of $70 \mathrm{~h}$ in a GIPET ${ }^{\mathrm{TM}}$ formulation was published in 2019 by Novo Nordisk [55]. In this study, a relative oral $\mathrm{F}$ versus the long-acting s.c.-administered insulin glargine (Lantus ${ }^{\circledR}$, Sanofi, Paris) of $1.5-2.0 \%$ was achieved without evidence of toxicity over eight weeks. Although similar plasma glucose reduction was achieved by the oral GIPET ${ }^{\mathrm{TM}}$-based formulation to the s.c. insulin, the rationale for discontinuation was that the dose of I338 was not commercially viable. The GIPET ${ }^{\mathrm{TM}}$ journey with oral peptides and poorly permeable small molecules, therefore, ended without generating a product in 2015. As a post-script, a Phase I study was published in 2018 by Biocon (India) in which a $\mathrm{C}_{10}$-based formulation of their alkylated PEGylated fast-acting meal-time insulin (IN-105; Insulin Tregopil) was shown to have no effect on the PK of oral metformin in fasted conditions and it was well tolerated [56]. Therefore, $\mathrm{C}_{10}$ continues to be used in oral peptide formulations both in clinical trials and as a comparator for other PEs in preclinical studies.

The other arm of the original Elan licensing of $\mathrm{C}_{10}$-based matrix tablets in the late 1990s continued in parallel with respect to antisense oligonucleotides. The gene medicine specialty Pharma, Ionis Pharmaceuticals (Carlsbad, CA, USA) (formerly Isis Pharma) developed a number of oral antisense oligonucleotide formulations containing $\mathrm{C}_{10}$ for clinical testing against RNA targets. One candidate that progressed to Phase I was ISIS 104838, a tumor necrosis factor (TNF)- $\alpha$ inhibitor. Oral administration of a $C_{10}$-based tablet to dogs resulted in average absolute oral BA of $1.4 \%$ [57]. Tissue histology of the small intestine and large intestine of the dogs indicated no changes following once-daily dosing of tablets containing $\sim \mathrm{g}$ of $\mathrm{C}_{10}$ over seven consecutive days. A subsequent Phase I trial examined ISIS 104838 (100 or $140 \mathrm{mg}$ ) formulated with $\mathrm{C}_{10}(660 \mathrm{mg})$ in immediate-release mini-tablets packaged in enteric-coated gelatin capsules, with or without a second mini-tablet containing only $\mathrm{C}_{10}$. The second group of mini-tablets was coated with different layers of Eudragit ${ }^{\circledR}$ RS30D to allow for subsequent further release of the $\mathrm{C}_{10}$ following erosion of the first tablet containing ISIS 104838 [58]. The goal was to create a greater window for absorption by prolonging the time $C_{10}$ was in contact with the epithelium, given that it is rapidly absorbed with a $\mathrm{T}_{\max }$ of $7 \mathrm{~min}$. All formulations together yielded an average oral BA of $9.5 \%$ relative to s.c. injection, with the formulation designed for additional immediate release of $\mathrm{C}_{10}$ giving a value of $12 \%$; however, the intra-subject variability ranged from 2-28\% [58]. In 2017, Ionis advanced an oral antisense molecule IONIS-JBI1-2.5Rx, aimed at an RNA target associated with a GI autoimmune disorder, to Phase I trials in collaboration with Janssen (Beerse, Belgium) [59]; however, it is unlikely that the formulation contains $C_{10}$ as it is designed for local colonic delivery. Table 1 summarizes the clinical data reported for a range of poorly permeable molecules with $\mathrm{C}_{10}$. Of these, there are only four peer-reviewed original research papers for GIPET ${ }^{\mathrm{TM}}$ tablets. 
Table 1. Summary of data from selected studies in humans reported for a range of poorly permeable molecules formulated with sodium caprate $\left(\mathrm{C}_{10}\right)$.

\begin{tabular}{|c|c|c|c|}
\hline Description & Treatment & Outcome & Reference \\
\hline $\begin{array}{l}\text { Ampicillin with } C_{10} \text { in } \\
\text { healthy subjects }(n=12) .\end{array}$ & $\begin{array}{l}\text { Rectal suppository containing } \\
250 \mathrm{mg} \text { of ampicillin and } 25 \mathrm{mg} \\
\text { of } C_{10} .\end{array}$ & $\begin{array}{c}\mathrm{C}_{\max } \text { increased 2.6-fold compared } \\
\text { to ampicillin alone and BA } \\
\text { increased 1.8-fold. Some local } \\
\text { tissue damage not ascribed to } \mathrm{C}_{10} \text {. }\end{array}$ & [17] \\
\hline $\begin{array}{l}\text { Phenoxymethylpenicillin, } \\
\text { antipyrine with } C_{10} \text { in } \\
\text { healthy subjects }(n=6) \text {. }\end{array}$ & $\begin{array}{l}\text { Rectal perfusion containing } 2 \mathrm{~g} \text { of } \\
\text { phenoxymethylpenicillin, } 8 \mathrm{mg} \text { of } \\
\text { antipyrine, and } 0.7 \mathrm{~g} \text { of } \mathrm{C}_{10} \text {. Two } \\
\text { treatments }(\mathrm{T}), \mathrm{T} 1 \mathrm{pH} 6 \text { and } \mathrm{T} 2 \text { : } \\
\mathrm{pH} 7.4 \text {. Each subject received } \\
\text { control }\left(\text { no } \mathrm{C}_{10} \text { ) and treatment. }\right.\end{array}$ & $\begin{array}{c}\mathrm{C}_{10} \text { was ineffective at increasing } \\
\text { permeability across rectal } \\
\text { epithelium. }\end{array}$ & [60] \\
\hline $\begin{array}{l}\text { GIPET }^{\mathrm{TM}} \text { : oral acyline in } \\
\text { healthy subjects }(n=8) \text {. }\end{array}$ & $\begin{array}{c}3 \text { oral tablet doses of acyline: } 10, \\
\text { 20, and } 40 \text { mg. Subjects received } \\
\text { all doses, } 1 \text { week apart, under } \\
\text { fasting conditions. }\end{array}$ & $\begin{array}{l}\text { Significant reduction in LH, FSH, } \\
\text { and testosterone. No serious } \\
\text { treatment related adverse effects. }\end{array}$ & [53] \\
\hline $\begin{array}{l}\text { GIPET }^{\mathrm{TM}} \text { : oral zoledronic } \\
\text { acid in prostate cancer } \\
\text { patients with bone } \\
\text { metastasis }(n=30)\end{array}$ & $\begin{array}{l}\text { Once-weekly enteric-coated } \\
\text { Orazol }{ }^{\mathrm{TM}} \text { tablets containing } 20 \mathrm{mg} \\
\text { of zoledronic acid versus weekly } \text { Zometa }^{\circledR}(4 \mathrm{mg}) \text { i.v. infusion over } \\
49 \text { days. }\end{array}$ & $\begin{array}{c}\text { Equivalent urine output } \\
\text { biomarkers; claim of } 5 \% \\
\text { bioavailability (BA) in patent. }\end{array}$ & [54] \\
\hline $\begin{array}{l}\text { Antisense oligonucleotide } \\
\left.\text { with } C_{10} \text { (ISIS } 104838\right) \text { in } \\
\text { healthy subjects }(n=15)\end{array}$ & $\begin{array}{c}\text { Enteric-coated tablets, four } \\
\text { formulations, and one after a } \\
\text { high-fat meal. Subjects received } \\
\text { all treatments. }\end{array}$ & $\begin{array}{l}\text { 9.5\% bioavailability compared to } \\
\text { s.c. No study-related adverse } \\
\text { effects. }\end{array}$ & [58] \\
\hline $\begin{array}{l}\text { Basal insulin in } \mathrm{C}_{10} \\
\text { formulation versus insulin } \\
\text { glargine in Type } 2 \text { diabetics } \\
\text { (s.c.) }(n=25) \text {. }\end{array}$ & $\begin{array}{l}\text { Daily tablets of a long-acting } \\
\text { insulin (I338) over } 8 \text { weeks. }\end{array}$ & $\begin{array}{c}1.5-2.0 \% \text { bioavailability compared } \\
\text { to s.c. Comparable reductions in } \\
\text { plasma glucose. }\end{array}$ & [55] \\
\hline $\begin{array}{l}\text { Insulin tregopil (IN-105) in } \\
\mathrm{C}_{10} \text { tablets in healthy } \\
\text { subjects. }\end{array}$ & $\begin{array}{l}\text { Single treatments of insulin along } \\
\text { with metoformin over } 4 \text { periods of } \\
2 \text { days. }\end{array}$ & $\begin{array}{l}\text { No effects on the } \\
\text { pharmacokinetics (PK) of } \\
\text { metformin; good safety. }\end{array}$ & [56] \\
\hline
\end{tabular}

LH, luteinizing hormone; FSH, follicle-stimulating hormone; s.c., sub-cutaneous; i.v., intravenous. The Phase II study [55] is the most comprehensive of these studies.

\subsection{SNAC}

SNAC was in a succession of clinical trials in oral formulations with poorly permeable actives since the late 1990s, culminating with approval for cyanocobalamin as a medical food for vitamin $B_{12}$-deficient anemic subjects in 2014 [20,21]. The initial clinical trials were carried out using unfractionated heparin in 1998 [61]. In the first Phase I study, $2.25 \mathrm{~g}$ of taste-masked SNAC was combined with 30,000-150,000 IU of heparin and administered to subjects via gavage; the formulation achieved increases in outputs associated with anti-coagulation efficacy: activated partial thromboplastin time (aPTT) and production of anti-factor Xa. This led to subsequent Phase I and II trials with taste-masked 10-15-mL liquid formulations in patients undergoing total hip replacements; oral heparin was dosed at either 60,000 or 90,000 IU with 1.5 or $2.25 \mathrm{~g}$ of SNAC respectively, and results were compared to s.c. administration of $5000 \mathrm{IU}$ of heparin [62]. The oral dosing regimen comprised 12-16 doses over a four-day period after surgery. Data from the second Phase I study showed that the oral heparin liquid formulation induced anti-factor Xa activity similar to s.c. heparin. In the Phase II trial, major bleeding events were similar between oral and s.c. heparin groups, thereby offering encouragement on the safety front. In 2002, the oral liquid heparin formulation ultimately missed its primary efficacy end-point in a Phase III trial (PROTECT) comparing oral heparin (either 60,000 IU/1.5 g SNAC or 90,000 IU/2.25 g SNAC three times a day) to s.c. LMWH (enoxaparin) over a 30-day period with assessment for deep vein thrombosis as the read-out. The study comprised over 2000 patients undergoing elective hip replacement, a study that was associated with poor compliance due to the bitter taste of the solution [49]. Direct leveraging from a taste-masked drink to a solid dosage form was not possible, due to the high quantities of SNAC and heparin. Subsequently, a new Phase I PK-PD study was eventually carried out in 2007 in 16 subjects receiving a 75,000 IU heparin/500 mg 
SNAC total dose in soft gel capsules [63]. It confirmed the effect on aPTT and the orally delivered heparin had a $\mathrm{C}_{\max }$ of $58 \mathrm{~min}$. Ultimately, a solid dose formulation of oral heparin/SNAC never reached Phase III and was abandoned, perhaps in part because of the advantages of LMWH over unfractionated heparin, as well as the advent of alternative oral anti-thrombotics.

In relation to other payloads and Eligen ${ }^{\circledR}$ carriers, a caprylic-acid derivative, possibly SNAC, was also formulated with sCT, and a Phase I study in eight volunteers was published in 2002, with a comprehensive analysis of PK [64]. This benchmark study described tablets of $0.4 \mathrm{mg}$ of sCT with $225 \mathrm{mg}$ of SNAC that were dosed singly, in duplicate, or in triplicate to present individual doses of $0.4,0.8$, and $1.2 \mathrm{mg}$ of sCT. The resulting absolute oral BA values versus an intravenous (i.v.) dose of $10 \mu \mathrm{g}$ ranged from $0.5-1.4 \%$. An Eligen ${ }^{\circledR}$ formulation of insulin was also assessed in a 2010 trial in 14 Type 2 diabetics (T2D) where the carrier was monosodium $\mathrm{N}$-(4-chlorosalicyloyl)-4-aminobutyrate (4-CNAB). An oral BA of $7 \pm 4 \%$ was achieved from a 300-IU dose (with 200-400 mg of 4-CNAB) versus an s.c. dose of $15 \mathrm{IU}$ in fasting subjects [65]. Such large variability would not be acceptable for this low-therapeutic-index drug. A third related Eligen ${ }^{\circledR}$ carrier, 8-(N-2-hydroxy-5-chloro-benzoyl)-amino-caprylic acid (5-CNAC), was also evaluated by Novartis (Switzerland) and Nordic Biosciences (Herlev, Denmark) in three large Phase III trials for oral sCT: two for osteoarthritis [66] (NCT00486434 and NCT00704847) and one for osteoporosis [67] (NCT00525798). The dosing to several thousand patients across the three trials comprised one tablet $(0.8 \mathrm{mg} \mathrm{sCT}$ with $200 \mathrm{mg}$ of 5-CNAC) in a tablet administered twice a day with $50 \mathrm{~mL}$ of water approximately $30 \mathrm{~min}$ ahead of meals. These studies lasted 24 months for the osteoarthritis trials and 36 months for the osteoporosis trial. Although these trials missed their primary efficacy end-points, interesting assessments concerning dosing formats and regimes were published with conclusions that may have relevance for SNAC trials [68]. Differences in SCT absorption and effects on bone biomarkers occurred depending on the volume of water, proximity to a meal, and the time of day (reflecting circadian rhythms in bone turnover). Table 2 summarizes the clinical trial performance of oral SNAC and related Emisphere carrier formulations across a range of poorly permeable molecules.

Table 2. Summary of data from selected studies in humans reported for a range of poorly permeable molecules formulated with either salcaprozate sodium (SNAC), monosodium N-(4-chlorosalicyloyl)4-aminobutyrate (4-CNAB), or 8-(N-2-hydroxy-5-chloro-benzoyl)-amino-caprylic acid (5-CNAC). T2D—type 2 diabetes; sCT-salmon calcitonin.

\begin{tabular}{|c|c|c|c|}
\hline Description & Treatment & Outcome & Reference \\
\hline $\begin{array}{l}\text { Vitamin } \mathrm{B}_{12} \text { with SNAC } \\
\text { in tablets in healthy } \\
\text { subjects }(n=20) \text {. Medical } \\
\text { food clinical study. }\end{array}$ & $\begin{array}{c}\text { (A) Two tablets, each with } 5 \mathrm{mg} \text { of } \\
\text { vitamin } \mathrm{B}_{12} \text { with } 100 \mathrm{mg} \text { of SNAC } \\
\text { (B) One tablet: } 5 \mathrm{mg} \text { of vitamin } \mathrm{B}_{12} \\
\text { with } 100 \mathrm{mg} \text { of SNAC } \\
\text { (C) One commercial tablet: } 5 \mathrm{mg} \\
\text { of vitamin } \mathrm{B}_{12} \\
\text { (D) } 1 \mathrm{mg} \text { of vitamin } \mathrm{B}_{12} \text { via i.v. } \\
\text { injection. }\end{array}$ & $\begin{array}{l}\text { Treatment }(\mathrm{B}) \text { achieved } 3 \% \\
\text { higher absolute BA compared } \\
\text { to the commercial oral } \\
\text { formulation. No } \\
\text { adverse effects. }\end{array}$ & [20] \\
\hline $\begin{array}{l}\text { Heparin with SNAC in } \\
\text { hip replacement patients, } \\
\quad(n=123) \text {. Phase II. }\end{array}$ & $\begin{array}{l}\text { Two studies: one dose every } 8 \mathrm{~h} \\
\text { (max } 16 \text { doses), and two doses } \\
\text { every } 8 \mathrm{~h}(\max 12 \text { doses). }\end{array}$ & $\begin{array}{c}\text { Achieved anti-factor Xa } \\
\text { activity comparable to s.c. } \\
\text { heparin. No change in major } \\
\text { bleeding events compared } \\
\text { to s.c. }\end{array}$ & [62] \\
\hline $\begin{array}{c}\text { Insulin with 4-CNAB in } \\
\text { untreated T2D }(n=10) . \\
\text { Phase II. }\end{array}$ & $\begin{array}{l}300 \mathrm{mg} \text { of insulin with } 400 \mathrm{mg} \text { of } \\
\text { 4-CNAB, or } 15 \mathrm{IU} \text { of insulin s.c. } \\
\text { Performed under fasting } \\
\text { conditions. }\end{array}$ & $\begin{array}{l}\mathrm{C}_{\mathrm{max}} \text { was higher and was } \\
\text { reached faster compared to s.c. } \\
\text { Shorter duration and high } \\
\text { subject variability. No } \\
\text { adverse effects. }\end{array}$ & [65] \\
\hline $\begin{array}{l}\text { sCT with } 5 \text {-CNAC in } \\
\text { osteoarthritic patients } \\
\text { over } 24 \text { months }(n=1176 \\
\text { and } n=1030) \text { Phase III. }\end{array}$ & $\begin{array}{l}0.8 \mathrm{mg} \text { of sCT in tablets twice } \\
\text { daily for } 24 \text { months. }\end{array}$ & $\begin{array}{l}\text { No significant effect compared } \\
\text { to placebo. }\end{array}$ & [66] \\
\hline $\begin{array}{l}\text { sCT with } 5 \text {-CNAC in } \\
\text { postmenopausal women } \\
\text { with osteoporosis } \\
(n=4665) . \text { Phase III. }\end{array}$ & $\begin{array}{l}0.8 \mathrm{mg} \text { or placebo in tablets daily, } \\
\text { together with vitamin } \mathrm{D} \text { and } \\
\text { calcium for } 36 \text { months. }\end{array}$ & $\begin{array}{l}\text { No beneficial effect on } \\
\text { fractures was observed. No } \\
\text { change in quality of life. }\end{array}$ & [6] \\
\hline
\end{tabular}


Recent focus, however, shifted entirely to the clinical development of the oral semaglutide/SNAC tablet by Novo Nordisk. Once-daily oral semaglutide with $300 \mathrm{mg}$ of SNAC resulted in improved glycemic control and greater reductions in body weight than placebo in a 26-week Phase II dose-escalation study in doses ranging from $2.5-40 \mathrm{mg}$ of semaglutide per day in over 600 patients with T2D [69]. Daily oral administration of semaglutide (20 mg and $40 \mathrm{mg}$ ) with SNAC lowered glycated hemoglobin $(\mathrm{HbA} 1 \mathrm{c})$ by over $1.4 \%$ and these data were comparable with that seen with weekly s.c. administration of semaglutide $(1 \mathrm{mg})$. For oral semaglutide with SNAC, the oral BA is likely to be $\sim 1 \%$, although the focus of the publications was on the PD effect and biomarkers. Clues come from Beagle dog studies where tablets containing $300 \mathrm{mg}$ of SNAC with 5-20 mg of semaglutide gave oral BA values of $1.22 \pm 0.25 \%$ following oral administration [52,70]. Novo Nordisk completed ten Phase IIIa PIONEER trials in 2018. Top-line data from PIONEER 1 achieved significance with respect to a reduction in $\mathrm{HbA} 1 \mathrm{c}$ of $1.5 \%$ with a 14-mg semaglutide dose in T2D, along with evidence of some weight loss [71]. Recent trials also revealed that renal impairment did not affect PK parameters of $5 \mathrm{mg}$ and $10 \mathrm{mg}$ of semaglutide formulated with $300 \mathrm{mg}$ of SNAC over a short time frame in diabetics [72]. This design was repeated in diabetic patients with hepatic impairment with the same outcome in that PK values were not altered and, therefore, no dose adjustment was needed in these patients [73]. The question of the impact of omeprazole on PK was also assessed, as elevation of bulk stomach pH might have confounded the purported mechanism of SNAC. Using a 5-mg semaglutide dose in patients taking $40 \mathrm{mg}$ of omeprazole over a 10-day period with a follow-up period out to 21 days, overall PK values for both semaglutide and SNAC were unchanged, leading to a conclusion that dose adjustment would be also unnecessary in patients on concomitant omeprazole [74]. The implications of these findings would support the determination that the $\mathrm{pH}$ increase created by SNAC in the stomach must be at the semaglutide tablet surface [52] and does not impact bulk stomach $\mathrm{pH}$; otherwise, a large effect of omeprazole on PK would have been expected. The PIONEER 6 Phase III study enrolled diabetics with cardiovascular disease in order to exam oral semaglutide PK and PD in this cohort to see if the daily 14-mg formulation increases cardiovascular risk [75]. Selected oral semaglutide clinical data are summarized in Table 3. It will be interesting to examine patient compliance with the current rather inconvenient dosing regime, especially in post-marketing studies if oral semaglutide is approved, since the daily tablet must be taken at least $30 \mathrm{~min}$ before meals in the morning in order to avoid food interference with formulation performance.

Table 3. Selected clinical trial data with an emphasis on peer-reviewed literature from the daily semaglutide/SNAC oral tablet formulation from Novo Nordisk in T2D patients.

\begin{tabular}{|c|c|c|c|}
\hline Description & Parameters & Comment & Reference \\
\hline $\begin{array}{l}\text { Phase II dose-ranging } \\
\text { 26-week study in } \\
\text { patients }(n=632) \\
\text { (NCT01923181). }\end{array}$ & $\begin{array}{l}\text { 0.7-1.9\% reduction in glycated } \\
\text { hemoglobin (HbA1c); some } \\
\text { weight reduction; mild } \\
\text { gastro-intestinal (GI) side } \\
\text { effects common. }\end{array}$ & $\begin{array}{l}\text { The key trial which supported } \\
\text { moving to Phase III. }\end{array}$ & [69] \\
\hline $\begin{array}{l}\text { PIONEER-1 Phase IIIa } \\
\text { 26-week study in } \\
\text { patients }(n=703) \\
\text { (NCT02906930). }\end{array}$ & $\begin{array}{l}\text { Mean } 1.5 \% \text { reduction in } \mathrm{HbA} 1 \mathrm{c} \\
\text { confirmed with } 14-\mathrm{mg} \text { dose; } \\
4.1-\mathrm{kg} \text { weight reduction; } \\
\text { mild-moderate nausea in } 16 \% \\
\text { versus } 6 \% \text { in placebo. }\end{array}$ & $\begin{array}{l}14 \mathrm{mg} \text { established as } \\
\text { semaglutide dose with } 300 \mathrm{mg} \\
\text { of SNAC in all studies. }\end{array}$ & [71] \\
\hline $\begin{array}{l}\text { PIONEER } 5 \text { Phase IIIa in } \\
\text { renal-impaired patients } \\
(n=71)(\text { NCT02014259). }\end{array}$ & $\begin{array}{c}5 \mathrm{mg} \text { of semaglutide for } 5 \text { days; } \\
10 \mathrm{mg} \text { for } 5 \text { days, assessed up to } \\
21 \text { days after; no change in } \\
\text { PK overall. }\end{array}$ & $\begin{array}{l}\text { Area under curve (AUC) and } \\
\text { half-life }\left(\mathrm{t}_{\frac{1}{2}}\right) \text { similar to regular } \\
\text { T2D patients, no need to } \\
\text { change dose regime. }\end{array}$ & [72] \\
\hline $\begin{array}{l}\text { Trial in hepatic-impaired } \\
\text { patients }(n=56) \\
\text { (NCT02016911). }\end{array}$ & Design as for PIONEER-5. & $\begin{array}{l}\text { AUC, } C_{\max } \text {, and } t_{\frac{1}{2}} \\
\text { unchanged, no need to change } \\
\text { in dose regime. }\end{array}$ & [73] \\
\hline
\end{tabular}


Table 3. Cont.

\begin{tabular}{|c|c|c|c|}
\hline Description & Parameters & Comment & Reference \\
\hline $\begin{array}{l}\text { Trial in healthy subjects }{ }^{1} \\
\quad \text { taking omeprazole } \\
(n=54)(\text { NCT02249871). }\end{array}$ & $\begin{array}{c}5 \mathrm{mg} \text { for } 5 \text { days, followed by } \\
10 \mathrm{mg} \text { for } 5 \text { days }) \pm 40 \mathrm{mg} \\
\text { omeprazole. }\end{array}$ & $\begin{array}{c}\text { AUC and stomach pH slightly } \\
\text { higher in } \\
\text { semaglutide/omeprazole } \\
\text { group, but no need to change } \\
\text { dose regime. }\end{array}$ & [74] \\
\hline $\begin{array}{l}\text { PIONEER-6 Phase IIIa } \\
\text { assessed cardiovascular } \\
(\mathrm{CV}) \text { risk in T2D patients } \\
(n=3183) \\
\text { (NCT02692716). }\end{array}$ & $\begin{array}{l}\text { Primary end-points: reduction in } \\
\text { major CV events over median } \\
\text { 16-month period. }\end{array}$ & $\begin{array}{l}\text { Cardiovascular (CV) outcomes } \\
\text { not different from placebo, but } \\
\text { suggestion of a mortality } \\
\text { benefit of oral tablet. }\end{array}$ & [75] \\
\hline
\end{tabular}

\section{Safety of SNAC and $C_{10}$ in Preclinical and Clinical Studies}

Although $C_{10}$ was previously marketed in a rectal product, this has limited relevance to the safety of an orally delivered tablet formulation. The approval of SNAC in an oral vitamin- $B_{12}$ medical food product, though encouraging, is also only partially informative. Nonetheless, the clinical trial experience with both PEs in hundreds of subjects over more than 20 years suggest that only very low numbers of subjects experienced side-effects that caused drop out from trials, and the majority of reports were related to mild GI effects including nausea and diarrhea for GIPET ${ }^{\mathrm{TM}}[18,42]$ and SNAC [69]. Reversibility studies performed with $C_{10}$ in humans using the lactulose:mannitol urinary excretion ratio (LMER) assay showed that, following intra-jejunal administration to human subjects, the enhancer only increased permeability in a 20-min window [42]. It seems that dilution, spreading, and rapid intestinal absorption of both $\mathrm{C}_{10}$ and SNAC prevents prolonged exposure in vivo. There is no direct evidence, even from studies with a duration as long as six months, that stomach or duodenal ulcers are caused by these PEs, nor that pathogens can gain entry across a compromised intestinal epithelium. Still, post-marketing surveillance will provide more safety data in the context of daily administration over several years, at least in the case of SNAC with both vitamin $\mathrm{B}_{12}$ and semaglutide in the event of Food and Drug Administration (FDA) approval. Additional safety experience for SNAC will be ascertained from extensive Phase III oral semaglutide trials, which will fully report in 2019.

In terms of preclinical safety data, the experience for both molecules is extensive. Numerous studies reveal little toxicity of high doses of $\mathrm{C}_{10}$ in rats, dogs, and pigs following oral administration alone and in combination with payloads $[18,42,76]$. In a study of the acute effects of a $C_{10}$-based dosage form (Orasense ${ }^{\mathrm{TM}}$ ) in Beagles, Raoof et al. provided evidence of the safety of oral hydroxypropyl methyl cellulose-coated $C_{10}$ /antisense tablets [57]. Several hundred milligrams of $C_{10}$ were used in each tablet and dogs received treatment three times per day for seven days. Clinical chemistry and blood biochemistry parameters were normal; the dogs tolerated the formulation and there was normal weight gain. Canine intestinal issues were also adjudged normal following macroscopic examination post mortem. Five separate canine daily tolerance studies revealed encouraging safety data for selected components of the GIPET I and II technology [42]. Similar studies were also carried out intra-intestinal catheterized pigs where $C_{10}$ was formulated with antisense oligonucleotides at doses up to $100 \mathrm{mg} / \mathrm{kg}$ of the MCFA; it was well tolerated following multiple doses and with little evidence of intestinal epithelial damage post mortem [77].

For SNAC, Riley et al. carried out a sub-chronic oral toxicity test of SNAC in rats and found a no observed adverse effect (NOAEL) level of $1 \mathrm{~g} / \mathrm{kg} /$ day in rats for up to 13 weeks; it was only a massive dose of $2 \mathrm{~g} / \mathrm{kg} /$ day that eventually caused significant mortality [78]. It was also examined for gestational toxicity in pregnant rats at oral doses up to $1 \mathrm{~g} / \mathrm{kg} /$ day where slight weight loss was seen; there was no effect on growth of pups, but some evidence of a small increase in the still-birth rate was noted [79]. Some GI effects including emesis and diarrhea were observed in studies involving 
monkeys at a dose of $\geq 1.8 \mathrm{~g} / \mathrm{kg} /$ day [80]. SNAC ultimately achieved provisional GRAS status as a food additive. The safety data from clinical and preclinical studies, therefore, raised no red flags for either agent in oral dosage forms at high concentrations with a wide range of actives tested to date. An important safety consideration is the high inter-subject variability typically associated with the low oral bioavailability values for all payloads tested with both PEs to date; formulation with these PEs will, therefore, not be suitable for molecules with low therapeutic indices.

It is clear that surfactant-based PEs cause a mild degree of reversible perturbation of the intestinal mucosa. The small intestinal epithelium is entirely renewed every $72 \mathrm{~h}$ [81]; there is a high rate of cellular turnover and the intestine has a high capacity to replace cells, due to migrating stem cells from the intestinal crypt. There is also a reserve of stem cells that are dormant until epithelial injury occurs, at which point they are recruited to assist with restoration [82]. The capacity of the intestinal mucosa to repair is also associated with secretion of mucus, prostaglandins, and bicarbonate [80]. For a comprehensive review of repair and restoration of the intestinal barrier, see Blikslager et al. [38]. The capacity for epithelial repair following $C_{10}$ exposure was investigated in rat jejunal instillations, where full restitution was seen within $60 \mathrm{~min}$ of exposure [83]. These data were similar to that seen in rat models with other PEs including bile salts [84] and sodium dodecyl sulfate (SDS) [85]. Since $\mathrm{C}_{10}$ and SNAC are rapidly and completely absorbed, one interpretation is that, following local and transient mucosal perturbation leading to a transient increase in permeability, the epithelium recovers due to gradual dilution of the PE.

Another concern over routine use of PEs is based on their potential capacity to promote microbiome changes and absorption of microorganisms, antigens, and toxins leading to local inflammation, autoimmune disease, and sepsis [86]. Surfactants may impair the protective mucus layer, facilitating the diffusion of luminal bacteria to the intestinal epithelium and ultimately disturbing the host microbiota [87]. In a recent study which generated much debate, evidence was provided that the approved excipient emulsifiers, polysorbate-80 and carboxymethyl cellulose, disturb microbiota composition and induce obesity in mice [88]. Whether these data have any true significance for humans is not known at this point, but it is clear that intestinal microbiome research is going to become more relevant in toxicology profiling of oral formulations. A second concern that is continually raised is the potential increase in permeability of bystander molecules arising from tissue damage induced by PEs $[89,90]$. Taking into account the precise conditions required for permeation enhancement (high concentrations of payload and PE contemporaneously at the intestinal epithelium), as well as the marked difference in the MW of candidate payloads $(<10 \mathrm{kDa})$ compared to that of typical bacteria, viruses, and bacterial lipopolysaccharide (LPS) (>100 kDa), this concern may be overstated. Nonetheless, clinical pharmacology data from binge-drinking human subjects suggests that alcohol can permit absorption of endotoxins and can promote elevation of type 1 cytokines in plasma, akin to a low-grade infection [91]; thus, together with the study of relevant microbiome changes, more research is needed to filter the true toxicological risks of orally delivered PEs following chronic exposure.

Several studies describe an anti-microbial effect of $C_{10}$ at high concentrations. Cox et al. [92] demonstrated the bactericidal property of $\mathrm{C}_{10}$ against Salmonella typhimurium, and it also prevented its attachment to intestinal epithelia. Moreover, there was no evidence from the same study that $\mathrm{C}_{10}$ promoted permeation of this gut pathogen across isolated rat intestinal mucosa. At low $\mathrm{mM}$ concentrations, $\mathrm{C}_{10}$ is also bactericidal against Helicobacter pylori [93]. In an in vivo study with chickens, incorporation of $\mathrm{C}_{10}$ in feed at a level of $3 \mathrm{~g} / \mathrm{kg}$ protected them from colonization by Salmonella enterica [94]. Finally, capric acid has antifungal activities on Microsporium gypsum mycelia and spores in vitro [95]. These data are consistent with the well-known anti-microbial actions of MCFAs [96]. Although, to our knowledge, similar data are not reported for SNAC, it would be surprising if, upon examining its structure, it did not have similar anti-microbial actions. 


\section{Conclusions}

In comparing the safety and efficacy of $\mathrm{C}_{10}$ and SNAC as PEs in preclinical and clinical studies, examination of 20-30 years of literature would suggest that several of the key parameters are similar. Both can permit oral bioavailability of a range of macromolecular payloads by $<5 \%$, with mean values closer to $\sim 1 \%$. The SNAC clinical PK data with semaglutide seem to be on a par with previous performance, for example, with sCT; however, it is due to its formulation with a potent peptide with a long $t_{\frac{1}{2}}$ and high TI that is of particular interest. It is the long $t_{\frac{1}{2}}$ that can compensate for large intra-subject variability [52]. Aspects that tip the balance to SNAC compared to $C_{10}$ include the following: broader clinical experience and an approved vitamin $B_{12}$ product, more extensive toxicology studies and GRAS status, and the lack of requirement for protection against stomach acid. There is still controversy over the mechanism of action of SNAC; techniques including surface plasmon resonance and ITC are now providing data that suggest that the non-covalent interaction of peptides with either SNAC or $\mathrm{C}_{10}$ is low affinity and quite similar for each agent. Moreover, while the literature seems to offer a consensus that $C_{10}$ (at low concentrations) acts on tight junctions via intracellular events, and at high concentrations via transcellular perturbation arising from its surfactant effect, there is not the same consensus concerning the mechanism of action of SNAC. The 1990s theory of an exclusive transcellular action arising from increased lipophilicity of a non-covalent complex between SNAC and the payload was not convincing. The new mechanism suggested for SNAC arising from ligated dog studies argues for a local increase in stomach $\mathrm{pH}$ around semaglutide, a mechanism that appears to be specific for this molecule. Finally, the main argument advanced for oral peptide delivery is improved convenience over needles leading to better compliance. Patients will, however, be required to wait $30 \mathrm{~min}$ before eating and drinking after taking tablets of semaglutide/SNAC each morning; thus, patients will ultimately decide if this is an inconvenience preferable to a once-a-week injection.

Author Contributions: All authors contributed conceptually, to drafting, to figure and table designs, and to the final editing.

Funding: This project received funding from the Science Foundation Ireland Grant 13/RC/2073, the CÚRAM Center for Medical Devices (DB); the EU Horizon 2020 Research and Innovation Program under Marie Skłodowska-Curie Grant agreement No 666010 (SF); and the French National Agency of Research and Technology, CIFRE grant number: 2016/0439, with additional support from Sanofi Pharma (CT).

Conflicts of Interest: In the past two years, D.B. consulted for on oral peptide delivery at Sanofi, AstraZeneca/ MedImmune, and Boehringer-Ingelheim. Sanofi (D.B., E.F.), Gattefosse (D.B.), and Nuritas (D.B.) provided research grant funding. The funding sponsors played no role in the article.

\section{References}

1. Fosgerau, K.; Hoffmann, T. Peptide therapeutics: Current status and future directions. Drug Discov. Today 2015, 20, 122-128. [CrossRef] [PubMed]

2. Usmani, S.S.; Bedi, G.; Samuel, J.S.; Singh, S.; Kalra, S.; Kumar, P.; Ahuja, A.A.; Sharma, M.; Gautam, A.; Raghava, G.P.S. THPdb: Database of FDA-approved peptide and protein therapeutics. PLoS ONE 2017, 12, e0181748. [CrossRef] [PubMed]

3. Lakkireddy, H.R.; Urmann, M.; Besenius, M.; Werner, U.; Haack, T.; Brun, P.; Alié, J.; Illel, B.; Hortala, L.; Vogel, R.; et al. Oral delivery of diabetes peptides-Comparing standard formulations incorporating functional excipients and nanotechnologies in the translational context. Adv. Drug Deliv. Rev. 2016, 106, 196-222. [CrossRef] [PubMed]

4. Cowan Report. Therapeutic Categories Outlook: Comprehensive Study; Cowan \& Co.: New York, NY, USA, 2014.

5. Lewis, A.L.; Richard, J. Challenges in the delivery of peptide drugs: An industry perspective. Ther. Deliv. 2015, 6, 149-163. [CrossRef]

6. Aguirre, T.A.; Teijeiro-Osorio, D.; Rosa, M.; Coulter, I.S.; Alonso, M.J.; Brayden, D.J. Current status of selected oral peptide technologies in advanced preclinical development and in clinical trials. Adv. Drug Deliv. Rev. 2016, 106, 223-241. [CrossRef] [PubMed] 
7. Benet, L.Z. The drug transporter-metabolism alliance: Uncovering and defining the interplay. Mol. Pharm. 2009, 6, 631-643. [CrossRef] [PubMed]

8. $\quad$ Eligen ${ }^{\circledR}$ Technology: Summary and Value Proposition. Available online: https://www.emisphere.com/wpcontent/uploads/2017/02/Eligen-Technology-Presentation_2.15-Update.pdf (accessed on 12 February 2019).

9. Baluom, M.; Friedman, M.; Assaf, P.; Haj-Yehia, A.I.; Rubinstein, A. Synchronized release of sulpiride and sodium decanoate from HPMC matrices: A rational approach to enhance sulpiride absorption in the rat intestine. Pharm. Res. 2000, 17, 1071-1076. [CrossRef] [PubMed]

10. Maher, S.; Mrsny, R.J.; Brayden, D.J. Intestinal permeation enhancers for oral peptide delivery. Adv. Drug Deliv. Rev. 2016, 106, 277-319. [CrossRef] [PubMed]

11. Card, J.W.; Magnuson, B.A. A review of the efficacy and safety of nanoparticle-based oral insulin delivery systems. Am. J. Physiol. Gastrointest. Liver Physiol. 2011, 301, G956-G967. [CrossRef]

12. Banerjee, A.; Mitragotri, S. Intestinal patch systems for oral drug delivery. Curr. Opin. Pharmacol. 2017, 36, 58-65. [CrossRef] [PubMed]

13. Whitehead, K.; Karr, N.; Mitragotri, S. Safe and effective permeation enhancers for oral drug delivery. Pharm. Res. 2008, 25, 1782-1788. [CrossRef] [PubMed]

14. Maher, S.; Ryan, B.; Duffy, A.; Brayden, D.J. Formulation strategies to improve oral peptide delivery. Pharm. Pat. Anal. 2014, 3, 313-336. [CrossRef] [PubMed]

15. Aungst, B.J. Absorption enhancers: Applications and advances. AAPS J. 2012, 14, 10-18. [CrossRef] [PubMed]

16. EFSA Panel on Food Additives and Nutrient Sources added to Food (ANS); Younes, M.; Aggett, P.; Aguilar, F.; Crebelli, R.; Dusemund, B.; Filipič, M.; Frutos, M.J.; Galtier, P.; Gott, D.; et al. Re-evaluation of sodium, potassium and calcium salts of fatty acids (E 470a) and magnesium salts of fatty acids (E 470b) as food additives. EFSA J. 2018. [CrossRef]

17. Lindmark, T.; Söderholm, J.D.; Olaison, G.; Alván, G.; Ocklind, G.; Artursson, P. Mechanism of absorption enhancement in humans after rectal administration of ampicillin in suppositories containing sodium caprate. Pharm. Res. 1997, 14, 930-955. [CrossRef] [PubMed]

18. Walsh, E.; Adamczyk, B.; Chalasani, K.B.; Maher, M.; O’Toole, E.B.; Fox, J.; Leonard, T.W.; Brayden, D.J. Oral delivery of macromolecules: Rationale underpinning Gastrointestinal Permeation Enhancement Technology $\left(\right.$ GIPET $\left.^{\circledR}\right)$. Ther. Deliv. 2011, 2, 1595-1610. [CrossRef]

19. Leone-Bay, A.; Santiago, N.; Achan, D.; Chaudhary, K.; DeMorin, F.; Falzarano, L.; Haas, S.; Kalbag, S.; Kaplan, D.; Leipold, H.; et al. N-acylated alpha amino acids as novel oral delivery agents for proteins. J. Med. Chem. 1995, 38, 4263-4269. [CrossRef]

20. Castelli, M.C.; Wong, D.F.; Friedman, K.; Riley, M.G. Pharmacokinetics of oral cyanocobalamin formulated with sodium N-[8-(2-hydroxybenzoyl)amino]caprylate (SNAC): An open-label, randomized, single-dose, parallel-group study in healthy male subjects. Clin. Ther. 2011, 33, 934-945. [CrossRef]

21. Smith, L.; Mosley, J.; Ford, M.; Courtney, J. Cyanocobalamin/Salcaprozate Sodium: A novel way to treat vitamin $\mathrm{B}_{12}$ deficiency and anemia. J. Hematol. Oncol. Pharm. 2016, 6, 42-45.

22. Leone-Bay, A.; Paton, D.R.; Variano, B.; Leipold, H.; Rivera, T.; Miura-Fraboni, J.; Baughman, R.A.; Santiago, N. Acylated non-alpha-amino acids as novel agents for the oral delivery of heparin sodium, USP. J. Control. Release 1998, 50, 41-49. [CrossRef]

23. Goldberg, M. Gomez-Orellana I. Challenges for the oral delivery of macromolecules. Nat. Rev. Drug Discov. 2003, 2, 289-295. [CrossRef] [PubMed]

24. Leone-Bay, A.; Leipold, H.; Sarubbi, D.; Variano, B.; Rivera, T.; Baughman, R.A. Oral delivery of sodium cromolyn: Preliminary studies in vivo and in vitro. Pharm. Res. 1996, 13, 222-226. [CrossRef] [PubMed]

25. Anonymous, Sodium Decanoate, PubChem ID 16211937. Available online: https:// pubchem.ncbi.nlm.nih. gov / compound/16211937 (accessed on 12 February 2019).

26. Anonymous, Sodium Caprozate PubChem ID 22669833. Available online: https:/ / pubchem.ncbi.nlm.nih. gov/compound / 23669833 (accessed on 12 February 2019).

27. Brayden, D.J.; Gleeson, J.; Walsh, E. A head-to-head multi-parametric high content analysis of a series of medium chain fatty acid intestinal permeation enhancers in Caco-2 cells. Eur. J. Pharm. Biopharm. 2014, 88, 830-839. [CrossRef] [PubMed] 
28. Khafagy, E.S.; Morishita, M.; Takayama, K. The role of intermolecular interactions with penetratin and its analogue on the enhancement of absorption of nasal therapeutic peptides. Int. J. Pharm. 2010, 388, 209-212. [CrossRef]

29. Twarog, C.; Hillaireau, H.; Taverna, M.; Noiray, M.; Illel, B.; Vogel, R.; Brayden, D.J.; Fattal, E. Oral peptide delivery: Understanding interactions between a peptide and permeation enhancers. In Proceedings of the 11th World Meeting on Pharmaceutics, Biopharmaceutics and Pharmaceutical Technology, Granada, Spain, 19-22 March 2018.

30. Lindmark, T.; Nikkila, T.; Artursson, P. Mechanisms of absorption enhancement by medium chain fatty acids in intestinal epithelial Caco-2 cell monolayers. J. Pharmacol. Exp. Ther. 1995, 275, 958-964.

31. Sawada, T.; Ogawa, T.; Tomita, M.; Hayashi, M.; Awazu, S. Role of paracellular pathway in nonelectrolyte permeation across rat colon epithelium enhanced by sodium caprate and sodium caprylate. Pharm. Res. 1991, 8, 1365-1371. [CrossRef]

32. Maher, S.; Kennelly, R.; Bzik, V.A.; Baird, A.W.; Wang, X.; Winter, D.; Brayden, D.J. Evaluation of intestinal absorption enhancement and local mucosal toxicity of two promoters. I. Studies in isolated rat and human colonic mucosae. Eur. J. Pharm. Sci. 2009, 38, 291-300. [CrossRef]

33. Tomita, M.; Hayashi, M.; Awazu, S. Absorption-enhancing mechanism of EDTA, caprate, and decanoylcarnitine in Caco-2 cells. J. Pharm. Sci. 1996, 85, 608-611. [CrossRef]

34. Lindmark, T.; Kimura, Y.; Artursson, P. Absorption enhancement through intracellular regulation of tight junction permeability by medium chain fatty acids in Caco-2 cells. J. Pharmacol. Exp. Ther. 1998, 284, 362-369.

35. Feighery, L.M.; Cochrane, S.W.; Quinn, T.; Baird, A.W.; O’Toole, D.; Owens, S.E.; O’Donoghue, D.; Mrsny, R.J.; Brayden, D.J. Myosin light chain kinase inhibition: Correction of increased intestinal epithelial permeability in vitro. Pharm. Res. 2008, 2, 1377-1386. [CrossRef]

36. Shimazaki, T.; Tomita, M.; Sadahiro, S.; Hayashi, M.; Awazu, S. Absorption-enhancing effects of sodium caprate and palmitoyl carnitine in rat and human colons. Dig. Dis. Sci. 1998, 43, 641-645. [CrossRef] [PubMed]

37. Krug, S.M.; Amasheh, M.; Dittmann, I.; Christoffel, I.; Fromm, M.; Amasheh, S. Sodium caprate as an enhancer of macromolecule permeation across tricellular tight junctions of intestinal cells. Biomaterials 2013, 34, 275-282. [CrossRef] [PubMed]

38. Blikslager, A.T.; Moeser, A.J.; Gookin, J.L.; Jones, S.L.; Odle, J. Restoration of barrier function in injured intestinal mucosa. Physiol. Rev. 2007, 87, 545-564. [CrossRef]

39. Sugibayashi, K.; Onuki, Y.; Takayama, K. Displacement of tight junction proteins from detergent-resistant membrane domains by treatment with sodium caprate. Eur. J. Pharm. Sci. 2009, 36, 46-253. [CrossRef]

40. Maher, S.; Heade, J.; McCartney, F.; Waters, S.; Bleiel, S.B.; Brayden, D.J. Effects of surfactant-based permeation enhancers on mannitol permeability, histology, and electrogenic ion transport responses in excised rat colonic mucosae. Int. J. Pharm. 2018, 539, 11-22. [CrossRef] [PubMed]

41. Brayden, D.J.; Maher, S.; Bahar, B.; Walsh, E. Sodium caprate-induced increases in intestinal permeability and epithelial damage are prevented by misoprostol. Eur. J. Pharm. Biopharm. 2015, 94, 194-206. [CrossRef]

42. Leonard, T.W.; Lynch, J.; McKenna, M.J.; Brayden, D.J. Promoting absorption of drugs in humans using medium-chain fatty acid-based solid dosage forms: GIPET. Exp. Opin. Drug Deliv. 2006, 3, 685-692. [CrossRef]

43. Gradauer, K.; Nishiumi, A.; Unrinin, K.; Higashino, H.; Kataoka, M.; Pedersen, B.L.; Buckley, S.T.; Yamashita, S. Interaction with mixed micelles in the intestine attenuates the permeation enhancing potential of alkyl-maltosides. Mol. Pharm. 2015, 12, 2245-2253. [CrossRef]

44. Brayden, D.; Creed, E.; O'Connell, A.; Leipold, H.; Agarwal, R.; Leone-Bay, A. Heparin absorption across the intestine: Effects of sodium N-[8-(2-hydroxybenzoyl)amino]caprylate in rat in situ intestinal instillations and in Caco-2 monolayers. Pharm. Res. 1997, 14, 1772-1779. [CrossRef]

45. Malkov, D.; Angelo, R.; Wang, H.Z.; Flanders, E.; Tang, H.; Gomez-Orellana, I. Oral delivery of insulin with the eligen technology: Mechanistic studies. Curr. Drug Deliv. 2005, 2, 191-197. [CrossRef]

46. Hess, S.; Rotshild, V.; Hoffman, A. Investigation of the enhancing mechanism of sodium $\mathrm{N}$-[8-(2-hydroxybenzoyl)amino]caprylate effect on the intestinal permeability of polar molecules utilizing a voltage clamp method. Eur. J. Pharm. Sci. 2005, 25, 307-312. [CrossRef] [PubMed]

47. Malkov, D.; Wang, H.Z.; Dinh, S.; Gomez-Orellana, I. Pathway of oral absorption of heparin with sodium N-[8-(2-hydroxybenzoyl)amino] caprylate. Pharm. Res. 2002, 19, 1180-1184. [CrossRef] [PubMed] 
48. Ding, X.; Rath, P.; Angelo, R.; Stringfellow, T.; Flanders, E.; Dinh, S.; Gomez-Orellana, I.; Robinson, J.R. Oral absorption enhancement of cromolyn sodium through noncovalent complexation. Pharm. Res. 2004, 21, 2196-2206. [CrossRef] [PubMed]

49. Arbit, E.; Goldberg, M.; Gomez-Orellana, I.; Majuru, S. Oral heparin: Status review. Thromb. J. 2006, 4, 6. [CrossRef] [PubMed]

50. Alani, A.W.; Robinson, J.R. Mechanistic understanding of oral drug absorption enhancement of cromolyn sodium by an amino acid derivative. Pharm. Res. 2008, 25, 48-54. [CrossRef] [PubMed]

51. Rehmani, S.; Dixon, J.E. Oral delivery of anti-diabetes therapeutics using cell penetrating and transcytosing peptide strategies. Peptides 2018, 100, 24-35. [CrossRef] [PubMed]

52. Buckley, S.T.; Bækdal, T.A.; Vegge, A.; Maarbjerg, S.J.; Pyke, C.; Ahnfelt-Rønne, J.; Madsen, K.G.; Schéele, S.G.; Alanentalo, T.; Kirk, R.K.; et al. Transcellular stomach absorption of a derivatized glucagon-like peptide-1 receptor agonist. Sci. Transl. Med. 2018, 10. [CrossRef]

53. Amory, J.K.; Leonard, T.W.; Page, S.T.; O’Toole, E.; McKenna, M.J.; Bremner, W.J. Oral administration of the GnRH antagonist acyline, in a GIPET-enhanced tablet form, acutely suppresses serum testosterone in normal men: Single-dose pharmacokinetics and pharmacodynamics. Cancer Chemother. Pharmacol. 2009, 64, 641-645. [CrossRef]

54. Leonard, T.W. Composition and Drug Delviery of Bisphosphonates. U.S. Patent 0,215,743 A1, 26 August 2010.

55. Halberg, I.B.; Lyby, K.; Wassermann, K.; Heise, T.; Zijlstra, E.; Plum-Morchel, L. Efficacy and safety of oral basal insulin versus subcutaneous insulin in type 2 diabetes: A randomised, double-blind Phase II trial. Lancet Diabetes Endocrinol. 2019. [CrossRef]

56. Khedkar, A.; Lebovitz, H.; Fleming, A.; Cherrington, A.; Jose, V.; Athalye, S.N.; Vishweswaramurthy, A. Impact of insulin tregopil and its permeation enhancer on pharmacokinetics of metformin in healthy volunteers: Randomized, open-label, placebo-controlled, crossover study. Clin. Transl. Sci. 2018. [CrossRef]

57. Raoof, A.A.; Chiu, P.; Ramtoola, Z.; Cumming, I.K.; Teng, C.; Weinbach, S.P.; Hardee, G.E.; Levin, A.A.; Geary, R.S. Oral bioavailability and multiple dose tolerability of an antisense oligonucleotide tablet formulated with sodium caprate. J. Pharm. Sci. 2004, 93, 1431-1439. [CrossRef] [PubMed]

58. Tillman, L.G.; Geary, R.S.; Hardee, G.E. Oral delivery of antisense oligonucleotides in man. J. Pharm. Sci. 2008, 97, 225-236. [CrossRef] [PubMed]

59. Available online: http://ir.ionispharma.com/news-releases/news-release-details/ionis-pharmaceuticalslicenses-first-oral-antisense-drug-acting (accessed on 12 February 2019).

60. Lennernäs, H.; Gjellan, K.; Hallgren, R.; Graffner, C. The influence of caprate on rectal absorption of phenoxymethylpenicillin: Experience from an in-vivo perfusion in humans. J. Pharm. Pharmacol. 2002, 54, 499-508. [CrossRef] [PubMed]

61. Baughman, R.A.; Kapoor, S.C.; Agarwal, R.K.; Kisicki, J.; Catella-Lawson, F.; FitzGerald, G.A. Oral delivery of anticoagulant doses of heparin. A randomized, double-blind, controlled study in humans. Circulation 1998, 98, 1610-1615. [CrossRef] [PubMed]

62. Berkowitz, S.D.; Marder, V.J.; Kosutic, G.; Baughman, R.A. Oral heparin administration with a novel drug delivery agent (SNAC) in healthy volunteers and patients undergoing elective total hip arthroplasty. J. Thromb. Haemost. 2003, 1, 1914-1919. [CrossRef] [PubMed]

63. Mousa, S.A.; Zhang, F.; Aljada, A.; Chaturvedi, S.; Takieddin, M.; Zhang, H.; Chi, L.; Castelli, M.C.; Friedman, K.; Goldberg, M.M.; et al. Pharmacokinetics and pharmacodynamics of oral heparin solid dosage form in healthy human subjects. J. Clin. Pharmacol. 2007, 47, 1508-1520. [CrossRef] [PubMed]

64. Buclin, T.; Cosma Rochat, M.; Burckhardt, P.; Azria, M.; Attinger, M. Bioavailability and biological efficacy of a new oral formulation of salmon calcitonin in healthy volunteers. J. Bone Miner. Res. 2002, 17, 1478-1485. [CrossRef] [PubMed]

65. Kapitza, C.; Zijlstra, E.; Heinemann, L.; Castelli, M.C.; Riley, G.; Heise, T. Oral insulin: A comparison with subcutaneous regular human insulin in patients with type 2 diabetes. Diabetes Care 2010, 33, 1288-1290. [CrossRef] [PubMed]

66. Karsdal, M.A.; Byrjalsen, I.; Alexandersen, P.; Bihlet, A.; Andersen, J.R.; Riis, B.J.; Bay-Jensen, A.C.; Christiansen, C.; CSMC021C2301/2 investigators. Treatment of symptomatic knee osteoarthritis with oral salmon calcitonin: Results from two phase 3 trials. Osteoarthr. Cartil. 2015, 23, 532-543. [CrossRef] 
67. Henriksen, K.; Byrjalsen, I.; Andersen, J.R.; Bihlet, A.R.; Russo, L.A.; Alexandersen, P.; Valter, I.; Qvist, P.; Lau, E.; Riis, B.J.; et al. SMC021 investigators., A randomized, double-blind, multicenter, placebo-controlled study to evaluate the efficacy and safety of oral salmon calcitonin in the treatment of osteoporosis in postmenopausal women taking calcium and vitamin D. Bone 2016, 91, 122-129. [CrossRef]

68. Karsdal, M.A.; Henriksen, K.; Bay-Jensen, A.C.; Molloy, B.; Arnold, M.; John, M.R.; Byrjalsen, I.; Azria, M.; Riis, B.J.; Qvist, P.; et al. Lessons learned from the development of oral calcitonin: The first tablet formulation of a protein in phase III clinical trials. J. Clin. Pharmacol. 2011, 51, 460-471. [CrossRef] [PubMed]

69. Davies, M.; Pieber, T.R.; Hartoft-Nielsen, M.L.; Hansen, O.K.H.; Jabbour, S.; Rosenstock, J. Effect of oral semaglutide compared with placebo and subcutaneous semaglutide on glycemic control in patients with Type 2 diabetes: A Randomized Clinical Trial. JAMA 2017, 318, 1460-1470. [CrossRef] [PubMed]

70. Bjerregaard, S.; Nielsen, F.S.; Sauerberg, P. Solid Compositions Comprising a GLP-1 Agonist and a Salt of n-(8-(2-Hydroxybenzoyl)Amino)Caprylic Acid. U.S. Patent WO2012080471A1, 8 March 2016.

71. Available online: https://globenewswire.com/news-release/2018/02/22/1379640/0/en/Novo-Nordisksuccessfully-completes-the-first-phase-3a-trial-PIONEER-1-with-oral-semaglutide.html (accessed on 28 November 2018).

72. Granhall, C.; Søndergaard, F.L.; Thomsen, M.; Anderson, T.W. Pharmacokinetics, safety and tolerability of oral semaglutide in subjects with renal impairment. Clin. Pharm. 2018, 57, 1571-1580. [CrossRef] [PubMed]

73. Baekdal, T.A.; Thomsen, M.; Kupčová, V.; Hansen, C.W.; Anderson, T.W. Pharmacokinetics, safety, and tolerability of oral semaglutide in subjects with hepatic impairment. J. Clin. Pharmacol. 2018, 58, 1314-1323. [CrossRef] [PubMed]

74. Bækdal, T.A.; Breitschaft, A.; Navarria, A.; Hansen, C.W. A randomized study investigating the effect of omeprazole on the pharmacokinetics of oral semaglutide. Expert Opin. Drug Metab. Toxicol. 2018, 14, 869-877. [CrossRef] [PubMed]

75. Bain, S.C.; Mosenzon, O.; Arechavaleta, R.; Bogdański, P.; Comlekci, A.; Consoli, A.; Deerochanawong, C.; Dungan, K.; Faingold, M.C.; Farkouh, M.E.; et al. Cardiovascular safety of oral semaglutide in patients with type 2 diabetes: Rationale, design and patient baseline characteristics for the PIONEER 6 trial. Diabetes Obes. Metab. 2018. [CrossRef]

76. Maher, S.; Leonard, T.W.; Jacobsen, J.; Brayden, D.J. Safety and efficacy of sodium caprate in promoting oral drug absorption: From in vitro to the clinic. Adv. Drug Deliv. Rev. 2009, 61, 1427-1449. [CrossRef]

77. Raoof, A.A.; Ramtoola, Z.; McKenna, B.; Yu, R.Z.; Hardee, G.; Geary, R.S. Effect of sodium caprate on the intestinal absorption of two modified antisense oligonucleotides in pigs. Eur. J. Pharm. Sci. 2002, 17, 131-138. [CrossRef]

78. Riley, M.G.; Castelli, M.C.; Paehler, E.A. Subchronic oral toxicity of salcaprozate sodium (SNAC) in Sprague-Dawley and Wistar rats. Int. J. Toxicol. 2009, 28, 278-293. [CrossRef]

79. Riley, M.G.; York, R.G. Peri-and postnatal developmental toxicity of salcaprozate sodium (SNAC) in Sprague-Dawley rats. Int. J. Toxicol. 2009, 28, 266-277. [CrossRef]

80. McCartney FGleeson, J.; Brayden, D.J. Safety concerns over the use of intestinal permeation enhancers: A mini-review. Tissue Barriers 2016, 4, e1176822. [CrossRef] [PubMed]

81. Van der Flier, L.G.; Clevers, H. Stem cells, self-renewal, and differentiation in the intestinal epithelium. Annu. Rev. Physiol. 2009, 71, 241-260. [CrossRef]

82. Laine, L.; Takeuchi, K.; Tarnawski, A. Gastric mucosal defense and cytoprotection: Bench to bedside. Gastroenterology 2008, 135, 41-60. [CrossRef] [PubMed]

83. Wang, X.; Maher, S.; Brayden, D.J. Restoration of rat colonic epithelium after in situ intestinal instillation of the absorption promoter, sodium caprate. Ther. Deliv. 2010, 1, 75-82. [CrossRef]

84. Gookin, J.L.; Galanko, J.A.; Blikslager, A.T.; Argenzio, R.A. PG-mediated closure of paracellular pathway and not restitution is the primary determinant of barrier recovery in acutely injured porcine ileum. Am. J. Physiol. 2003, 285, G967-G979. [CrossRef] [PubMed]

85. Narkar, Y.; Burnette, R.; Bleher, R.; Albrecht, R.; Kandela, A.; Robinson, J.R. Evaluation of mucosal damage and recovery in the gastrointestinal tract of rats by a penetration enhancer. Pharm. Res. 2008, 25, 25-38. [CrossRef] [PubMed]

86. König, J.; Wells, J.; Cani, P.D.; García-Ródenas, C.L.; MacDonald, T.; Mercenier, A.; Whyte, J.; Troost, F.; Brummer, R.J. Human intestinal barrier function in health and disease. Clin. Transl. Gastroenterol. 2016, 7, e196. [CrossRef] 
87. Cani, P.D. Human gut microbiome: Hopes, threats and promises. Gut 2018, 67, 1716-1725. [CrossRef]

88. Chassaing, B.; Koren, O.; Goodrich, J.K.; Poole, A.C.; Srinivasan, S.; Ley, R.E.; Gewirtz, A.T. Dietary emulsifiers impact the mouse gut microbiota promoting colitis and metabolic syndrome. Nature 2015, 519, 92-96. [CrossRef]

89. Choonara, B.F.; Choonara, Y.E.; Kumar, P.; Bijukumar, D.; du Toit, L.C.; Pillay, V. A review of advanced oral drug delivery technologies facilitating the protection and absorption of protein and peptide molecules. Biotechnol. Adv. 2014, 32, 1269-1282. [CrossRef]

90. Tscheik, C.; Blasig, I.E.; Winkler, L. Trends in drug delivery through tissue barriers containing tight junctions. Tissue Barriers 2013, 1, e24565. [CrossRef] [PubMed]

91. Bala, S.; Marcos, M.; Gattu, A.; Catalano, D.; Szabo, G. Acute binge drinking increases serum endotoxin and bacterial DNA levels in healthy individuals. PLoS ONE 2014, 9, e96864. [CrossRef] [PubMed]

92. Cox, A.B.; Rawlinson, L.; Baird, A.W.; Bzik, V.; Brayden, D.J. In vitro interactions between the oral absorption promoter, sodium caprate (C10) and S. typhimurium in rat intestinal ileal mucosae. Pharm. Res. 2008, 25, 114-122. [CrossRef] [PubMed]

93. Petschow, B.W.; Batema, R.P.; Ford, L.L. Susceptibility of Helicobacter pylori to bactericidal properties of medium-chain monoglycerides and free fatty acids. Antimicrob. Agents Chemother. 1996, 40, 302-306. [CrossRef]

94. Van Immerseel, F.; De Buck, J.; Boyen, F.; Bohez, L.; Pasmans, F.; Volf, J.; Sevcik, M.; Rychlik, I.; Haesebrouck, F.; Ducatelle, R. Medium-chain fatty acids decrease colonization and invasion through hilA suppression shortly after infection of chickens with Salmonella enterica serovar Enteritidis. Appl. Environ. Microbiol. 2004, 70, 3582-3587. [CrossRef] [PubMed]

95. Chadeganipour, M.; Haims, A. Antifungal activities of pelargonic and capric acid on Microsporum gypseum. Mycoses 2001, 44, 109-112. [CrossRef] [PubMed]

96. Huang, C.B.; Alimova, Y.; Myers, T.M.; Ebersole, J.L. Short and medium-chain fatty acids exhibit antimicrobial activity for oral microorganisms. Arch. Oral Biol. 2011, 56, 650-654. [CrossRef]

(C) 2019 by the authors. Licensee MDPI, Basel, Switzerland. This article is an open access article distributed under the terms and conditions of the Creative Commons Attribution (CC BY) license (http:/ / creativecommons.org/licenses/by/4.0/). 